\title{
POET SIRIN: THE EVOLUTION OF HIS IDEOLOGICAL AND AESTHETIC VIEWS
}

\author{
Anvar Magdanurovich Sharipov, \\ Naberezhno Chelny State Pedagogical University, \\ 28 Nizametdinov Str., Naberezhnye Chelny, 423826, Russian Federation, \\ anvar41.41@mail.ru.
}

\begin{abstract}
The article studies cultural evolution of ideological and aesthetic views of Sirin (Sirin Khanifovich Batyrshin), the author of many poetical works, who made an enormous contribution to Tatar literature from the 1920s to 1950s. The novelty of the study is its aim to "fill in the blanks" in the poet's life and his creative path, identifying the features of his artistic expression by familiarizing the scholarly community with new facts derived from new sources, materials of literary criticism, and archives. The systematized data on the study of Sirin's works is based on the analysis of the articles, published in various newspapers and magazines, and scholars' monographs devoted to the analysis of literature in the 1920s - 1950s. The paper analyses Sirin's poetry according to newly discovered facts of his biography and specific features of that literary and historical era. Employing historical-comparative, typological and biographical methods of research, the article reveals literary connections among Sirin's poems and peculiarities of his dialogue with Eastern and Western culture. By studying the evolution of the poet's ideological and aesthetic views, we focus on the analysis of the stages in Sirin's creative work, the key trends in the development of his topics, characterization, motifs, and the dynamics of his genre buildup.
\end{abstract}

Key words: Tatar poetry, ideological and aesthetic views, literary connections, motives, genres.

Sirin (Sirin Khanifovich Batyrshin, 14.12.1896 - 23.11.1969) is one of those poets who made a huge contribution to the development of Tatar poetry of the $1920 \mathrm{~s}-1960$ s, its enrichment with new forms, expansion of its motifs, and the scope of genres through their constant poetic exploration.

The poet Sirin first appeared in the field of literature in 1919, but his works received proper evaluation only in the 1930s. F. Saifi-Kazanli, [Səifi-Kazanly, 1930], G. Nigmati, [Nig"məti, Sovet ədəbiiaty, 1930], [Nig"məti, Iaңalif, 1931], and Kh. Badig, [Bedig, 1932] were the first to express their opinions on his poetry in their articles, related to the issues of literature, even if those papers were not directly devoted to the study of the poet's work. The poet finally received more attention when his collection of poems called "Tamchylar" ("Raindrops") was published in 1931 in Latin script [Sirin, 1931]. The first article that analyzed Sirin's poetry was written by Zakir Gali [Gali, 1931]. Moreover, in 1931, this article was placed in the foreword of the poet's book called "Tamchylar".

The supremacy of the class-based ideological approach along with vulgar sociology in Tatar literature of the late 1920s and the 1930s prevented making an adequate evaluation of Sirin's poetry. His poem called "Kyshky Chechekler" ("The Win- ter Flowers") was published in the $12^{\text {th }}$ issue of the magazine "Sovet Edebiyati" ("Soviet Literature") in 1933 [Sirin, Sovet ədəbiiaty, 1933]. Being completely misunderstood and judged only through the prism of the class ideology, Sirin was negatively reviewed in the first issues of that magazine the following year. For instance, Gumer Gali blamed the poet for "neglecting the ideas of the socialist society" [Gali, 1934, pp. 92-93], and Nur Bayan stated that the poem "Kyshky Chechekler" did not reflect any relevant topics [Baian, 1934, pp. 9495]. At this point, it should be noted that at that time Nur Bayan was under the supervision of Sirin, the head of the Agriculture Department at Tatizdat ("the Tatar Publishing House").

These articles not only indicated that their author was sick with vulgar sociologism but also tarnished Sirin's good name. In his speech at the Writer's Congress of Tatarstan in 1935, Kavi Nadjmi accused the poet of "not being involved in the current literary process", "of fighting against the Soviet government and socialist system", "of having chosen the anti-revolutionary path", and "of clamoring against the Soviet Union" [Nәжmi, 1935, pp. 72-75].

K. Tinchurin, who also took part in the discussion of the report, happened to be in the same vein: 
"You would think that these rotten remains of human beings won't dare to express any liberal ideas anymore... If they fail to get fixed in kind fostering hands, then it's time to pass them to even more skilled fosters" [Tinchurin, 1935, pp. 72-75]. Mirsay Amir also sided with these wrongful accusations: "He comes from a kulak family and he was involved in Sultan-Galiev's movement. He is one of those who, since ancient times, couldn't accept our ideas. And now we must and will take different measures against him and his like" [Amir, 1935, pp. 66-68]. He called Sirin's poem "Teguche Kyz" ("The Seamstress") a "plain Sultan-Galievism". Obviously, this kind of statements had their consequences: on August 22nd in 1935, Sirin was charged with "conducting propaganda against the Soviet regime" and was exiled to Siberia for 5 years.

Sirin, whose name was forced to be forgotten, finally got his spiritual heritage recollected and received appropriate evaluation right after the historical truth and his good name had been restored. His 54-page collection of poems was published under Ziya Mansur's editorship [Sirin, 1959]. A significant contribution to the study of Sirin's poetry was made by a young writer, Magsum Latifullin. Working as a school teacher in Bavly, he got to know the poet, communicated with him closely, even visited the poet's hometown in Karakashly; he collected Sirin's poems in order to publish them. Later in 1959, he published his review of Sirin's book "Shigerler" ("Poems") [Latifullin, 1959].

When Sirin was still around, M. Latifullin, compiled two collections of the poet's works and brought them to the Tatar Publishing House. The poet's collection "Oktyabr' Nurlary" ("Rays of October'), containing 56 poems, was ready to be published in 1961. Latifullin wrote a foreword called "Sirin and His Poetry" specifically for that collection [Latifullin, Sirin arhivy saklana]. Another collection of poems called "Sailanma Eserler" ("Selected Works"), containing 34 poems, was created in 1963. For unknown reasons, none of these books was published.

Starting from the 1970s, many articles were published on Sirin's milestone jubilees. There was A. Sharipov's article called "Uzenchelekle Shagyyr" ("An Extraordinary Poet") for his $80^{\text {th }}$ Jubilee [Shəripov, 1976] and "Tribun Shagyyr" ("The Tribune Poet") of the same author for Sirin's $90^{\text {th }}$ anniversary [Sheripov, 1986], Safa Sabirov's records called "Davylly Yellar Jyrchisy" ("The Singer of the Stormy Years") [Sabirov, 1986] and the editorial of the magazine "Kazan Utlary" ("The Lights of Kazan") [Redaktsion məkalə, 1987]. These articles were written only to promote Sirin's already published poetic works and demonstrate his creative success. But scholar Bulat Sultanbekov was the first to reveal and bring to the public the story of the wrongful accusations and unlawful arrest of the poet. In Soviet times, many people were afraid even to pronounce Sirin's name, who was declared to be "the enemy of the people".

When the USSR collapsed, B. Sultanbekov studied many cases stored in the NKVD archive and in his articles "Sereng Ach, Sirin!" ("Reveal Your Secret, Sirin!") and "Sirin: Prervannyi Vzlet" ("Sirin: An Aborted Takeoff"), brought to light the pages of history that previously remained unknown [Soltanbekov, 1995, 21 iiul')] [Soltanbekov, 1995, 28 oktiabr']. R. Mustafin's articles "Taktashnyn Koundeshe" ("The Taktash's Rival") [Mostafin, 1996] and "Kysh Sairamyi Sandugach..." ("The Nightingale Doesn't Sing in Winter..."), written in honor of Sirin's $100^{\text {th }}$ anniversary, also added new information to the study of the poet's life and creative work.

In honor of Sirin's $100^{\text {th }}$ anniversary, A. Yunysov published an article "Kysh Sairamyi Sandugach" ("A Nightingale Doesn't Sing in Winter...") [Iunysov, 1996] and F. Galimullin wrote his "Kalemennen Tamdirip Kanyn..." ("Dripping His Blood from His Quill...") [Galimullin, 2015]. On Sirin's $110^{\text {th }}$ anniversary, A. Sharipov issued a paper called "Shagyr Sirinnen Tormish Khem Ijat Yuly" ("The Life and Creative Path of the Poet Sirin"), and a scientific conference dedicated to Sirin's creative work was held in the poet's hometown of Karakashly.

R. Khakimova, a deputy head of the Yutazinsky municipal district, Danil Salikhov, the Chairman of the Almetyevsk writers' organization, Anvar Sharipov, Sirin's younger brother Rifkat Mahasinovich Batyrshin and others made speeches during this event. To honor Sirin's $120^{\text {th }}$ anniversary (in 2016), the Republican Academic and Practical Research Conference of Teachers and Students of the Tatar Language and Literature was held in Yutazinsky secondary school. It was attended not only by the representatives of the Yutazy and Bavlinsky regions, but also the participants from Nizhnekamsk, Cheremshansky, Spassky, Novosheshminsky and Tuymazinsky districts of Bashkortostan. The $9-11^{\text {th }}$ grade students presented 19 reports in two workshops, teachers of the Tatar language and literature gave 11 reports, and 16 students of $5-7^{\text {th }}$ grades participated in 
Sirin's recitation competition. In the years 1990 2020, A. Sharipov was particularly successful in appraising Sirin's work for its achievements in Tatar literary studies, conveying its fruits to the reader, and promoting them: [Shəripov, 1997], [Shəripov, 1998], [Shəripov, 2011], [Shəripov, 2007], [Shəripov, 2014], [Shəripov, Kazan utlary, 2016, No. 12, pp. 128-129], [Shəripov, Kazan utlary, 2016, No.1], [Shəripov, Kazan utlary, 2016, No. 12, pp. 130-160] [Shəripov, Medeni жоmga, 2016] , [Shəripov, Islam həm terki den'ya.., 2016], etc.

The $12^{\text {th }}$ issue, 2015 , of the "Maidan" magazine is entirely devoted to Sirin's poetry and contains materials prepared by A. Sharipov: there are Sirin's fifty poems, four pieces of prose, one essay, B. Sultanbekov's, R. Mustafin's, F. Galimullin's, and A. Sharipov's articles on his poetry, memoirs by Kashif Rahim, S. Sabirov, L. Badikshan, Ya. Iganay, a list of Sirin's published books, and numerous photographs of his lifetime. As of today, this issue of the magazine is considered to be the most comprehensive publication on Sirin's work.

Memoirs of Sirin's coevals also play a significant role in studying his poetry. Such memoirs were written by Mirgalim Shakirzyanov, Karam Akhmetzyanov, Kashif Rahim, Ahmed Iskhaq, Shafig Kamaletdinov, Rafael Mustafin, Safa Sabirov, Luqman Badykshan, Yamash Igani, Ural Uralov, Magsum Latifullin, Rifkat Batyrshin, etc.

The poet Sirin (his full name was Mukhammadsayrin) was born on December 14, 1896, in Karakashly village in the Yutazinsky district of Tatarstan as the fifth child in Gilman Mukhammadkhanif's family. Later, he took the pseudonym Sirin for himself and went down in the history of literature with this very name.

Throughout his life, Sirin had to face the bitter hardships of poverty many times. In the poet's life, grief was followed by grief and one tragedy came after another. Sirin's elder brother and the younger one died due to starvation in the 1910s. Their house burned down in 1916; his family was forced to rebuild their house from scratch. During the Civil War, the Whites shelled their village and killed their cows and horses. During the famine of 1921, his mother, Hosnikamal, died of starvation. Devastated by this tragedy, Sirin wrote: "No matter how hard I had tried, I couldn't save my mother from death. My dear mother starved to death!.. There was no joy left in this world for me. What was I to do?.. I, too, got sick with pneumonia and typhoid fever, and after spending the rest of the winter in sickness, when I finally got back on my feet, I decided to go to Kazan hoping that maybe I wouldn't die there. But the famine was there too, one kilo of bread cost one million rubles. I was accommodated with a big house near Lake Kaban.'[Sirin, 2016, p. 160]. During the Civil War, his father was tied to a pillar of a mosque and beaten by the Whites "for being on the side of the communists"; he died shortly after the incident, not being able to recover from his wounds. All of those sufferings went through the very heart of the future poet. Such cruel, harsh trials of his fate accompanied Sirin throughout his life.

In the 1910s-1915s, while studying at Bayraka Madrasah in a neighboring village and seeing injustice, he made fun of the rich and mullah boys by composing ridicule poems and reading them at private gatherings organized in their madrasah or dormitory: "Bugen bai malae Akhmi / Akcha birde mullaga. / Mulla "Kirekmi!", Dise de, / Nishlepter kuly ala. / Akhmi de shatlandy echten: / "Ukymysam da maktar! ... / Shulai akcha birebire, / Uzen-uze ul satar." ("Today the rich boy Akhmi / gave money to the mullah. / Although the mullah said, "No need!", / Why did his hand take it?/ Akhmi rejoiced inside too:/ "He will praise me regardless of my efforts!... By giving money like that, / He will sell himself!") [Sirin arhivy, Latifullin mekalese]. Because of such speeches, children of the rich and mullahs, being full of hatred, started mocking at him. Despite this, the teenager never hesitated to say such words. Thus, when he was just a pupil, a sense of hatred for injustices in society arose in Sirin; as the years went by, it grew bigger and bigger, reaching its peak in the 1930s.

For the first time as a poet, Sirin addressed the public on February 16, 1914: it was the same day when a farewell ceremony for the prominent journalist and public figure Faridai-Fatima was held in Karakashly. Many people from all surrounding villages and towns gathered for this event. It was then that Sirin read his first poem "Furidai-Fatyma Khanym Rukhina" ("On the Name of Mrs. FaridaiFatima"). "Sin ulsen de, emma lefzan, / Sin megynei ulmeden. / Kerde jeseden kaberge, / Emma uzen kermedeł" [Sirin arhivy, Latifullin mekalese]. People found these words very pleasing; the villagers would later recall this poem of Sirin when talking about Faridai-Fatima. The lament was published in "Suyumbike" magazine the same year. Calling people to unite for plowing and sowing, he wrote his "Sarutlyq Jir" ("The Land for Wheatgrass"). These were only the fruits of the young poet's pen-testing period. Sirin worked as a 
teacher in his hometown from 1914 to 1917, in Asay in 1916, and the Aznakay School in 1917. He actively took part in arranging various literary events and social activities. That was how he faced the October Revolution, as a teacher. During his three-year teacher training program in Bugulma, he joined the Komsomol. After the establishment of the Tatar-Bashkir section of the first Komsomol cell (RCSM) in the Bugulma district, Sirin was elected the section's secretary.

$\mathrm{He}$ began to build Komsomol cells in Karakashly, Bayraka, Tat. Kandyz and other villages. It is also known that he, armed with weapons, took part in the Civil War. The events of the Pitchfork Uprising of 1920 also wound Sirin up. M. Latifullin's article states that Sirin almost got killed when he clashed with the Pitchwork rebels in Kodash village of the Bugulma district in March 1920.

Sirin started his creative work as a poet in 1919, during the time of the Civil War. As his first steps in literature, he presented his powerful poems that were inspired by the idea of the revolution and created by the flames of youth during his life in Bugulma. One after another, his poems were printed in the newspapers "Yakty Yul" in Bugulma, "Yana Kouch" in Samara, "Eshche" in Kazan, and "Kyzyl Sheriq" in Tomsk. Sirin's creative path, to an extent, can be divided into two periods: from the 1920s to the 1930s and from the 1940s to the 1960s. The first period of his art was particularly active, passionate, and versatile and it surely created a huge resonance in the literary community.

In the 1920s, the main topic of Sirin's work was the Civil War. His poems "Kyzylarmeec Khaty" ("A Letter of the Red Army Soldier", 1919), "Selam Sezge, Kyzyl Bourketler!" ("Hello to You, Red Eagles!", 1920), "Kyzyl Gaskerge" ("To the Red Army", 1922), "Atly Shlemnar" ("Helmets with Horses", 1927), "Kyzylarmeets Atlar" ("Red Army's Horses", 1928) all refer to this very topic. Each of them is filled with optimistic pathos, revolutionary romance, and true confidence in the future. F. Galimullin writes, "Generally speaking, the spirit of communist ideology's poetry of the 1920s can be called the optimistic one. It's because most of the poets, just like Kh. Taktash, believed that these events would one day bring happiness and well-being to many people. This hope is outstandingly vivid in Sirin's poem "Beznen Yourekler" ("Our Hearts") [Galimullin, 1998, p. 118].

The poet's work "Sickert Atyng! (Kavaleriya Marshi)", ("Ride Your Horse! (Cavalry
March,1925) was quite popular in the 1920s. His key priority in this poem was its initial rhyme: by means of alliteration, he used the words reminiscent of the sounds of horse hooves, emphasizing the poem's musicality: "Ey, komandir! / Bir komanda! / Souygen atym, / Chaptar atym! / Typtyp basyp, / At uinatyp, / Atlat atyng! / Atlat atyy!!" (Hey, Commander! / Give the command! / My favorite horse, / Flaxen Chestnut horse! / Totting clip-clop, / Playing with horse, / Ride your horse! / Ride your horse! [Sirin, 193, p. 6].

The poet praised the Red Guard and rejoiced in its success:

\begin{tabular}{|l|l|}
\hline $\begin{array}{l}\text { Atly shlemnar, } \\
\text { Sezge bulek jirym, } \\
\text { Tavyshlaryn uzegez } \\
\text { anlagyz! }\end{array}$ & Bir komanda: \\
Uram khalky, & JeingY yakyn! \\
Sez de sak bulygyz, & Typ-typ basyp, \\
Atlar kile, taptalmagyz! & At uinatyp, \\
Ey, comandir! & Sickert atyỵ! \\
& Sickert atyp̧! \\
('Helmets with horses, & Give the command: \\
My song is a gift to you, & The victory is close! \\
Interpret its sounds as you & The victory is close! \\
like! & Totting clip-clop \\
The people of the streets, & Playing with your horse, \\
Be careful, too, & Ride your horse! \\
Horses are coming, don't & Ride your horse!) [Sirin, \\
get trampled! & 1931, p. 7] \\
Hey, commander! & \\
\hline
\end{tabular}

When famine broke out in 1921, classes at the Bugulma Seminary were canceled. In his "Achlar Tavishy" ("The Voice of the Hungry") Sirin describes devastating details of famine: "Yarly ilge yarlylar bash; koumesh jirde tash, / Tourle chupchar, alabuta beznen ilde buldy ash. I Yuk ele, tuzmi kunel, jan tartysha, syzyla yurek, / Ber telem ikmek sorap tetri begyr, ouzele uzek ("The poor country is ruled by the poor / On golden, silver land there is stone, / Bits and pieces, and the weed are now our meal. / No, not yet, the mind can't take it, the soul is trembling, the heart is pounding, / Begging for a bite of bread, the bosom rattles and rips the soul apart.) [Sirin, 1968, p. 169]. Devoted to this social issue, the poet created works related to plowing "Yaz - Igenchege" ("Spring Is for Ploughmen", 1922) and "Sarutlyk Jir" ("The Land for Wheatgrass", second version, 1924). In his first poem, he encouraged the villagers to start plowing fields as soon as possible: "Ashyk tizden - ulem birgun bu achlyk kitsen bezden" ("Hasten - make this deadly famine leave us"). In his "Sarutlyq Jir", 
the poet, encouraging soil cultivation based on scientific principles, said that the teachings of Marxism should also be considered.

From the very start of his literary work, Sirin looked up to Gabdullah Tukay's poetry and gained his own literary skill by learning from this great poet. Following in his footsteps, Sirin began writing classic forms of Oriental ghazals, qasidas, and mathnawi genres. Therefore, it is possible to draw typological parallels between Sirin's poems of the 1920s and the 1930s and Tukay's poetry. Common topics and similar imagery bind Tukay's "Eshtun Chygarylgan Tatar Kyzina" ("To a Wicked Tatar Girl”, 1909) and Sirin's "Avyl Kyzina" ("To a Village Girl", 1920) together: both describe a crying young Tatar girl, whose state of mind is expressed through such images and epithets as "meyus", "zalim", "kunel". But if Tukay's "zalim" ("a villain") is considered to be some Tatar rich man, Sirin's "zalim" symbolizes living an old-fashioned lifestyle. While Tukay describes his Tatar girl as being helpless, Sirin tries to comfort the crying girl, who misses her beloved young man who has gone to the Civil War: "Kup te utmes, meee kaytyp jiter / Jan soeklen koulech yoz belene", "Mene, kilechagen nindi matur / Rehetlenep gomer itersen" ("It won't be long till he comes back, / Your sweetheart with a smiling face", / "That's how beautiful your future is / You will live happily ever after") [Kyzyl Shərek", 1920, 6 avgust].

Tukay's "Dahige" ("To the Genuis", 1913) and Sirin's poem "Dingezge" ("To the Sea", 1920), besides being written in the mathnawi poetic form, also share similar rhymes and motifs. In his work, Tukay reflects on the national liberation movement and creates his character, the Genius, who seeks ways to save his dear nation from colonial persecution and bring it to the socio-cultural renewal. In his poem "Dingezge", Sirin discovers his new self, who is strong, passionate, rebellious, and does not obey to the waves of the sea. He calls after the sea:

\begin{tabular}{|l|l|}
\hline "Nindey dulkynnarga & Ul shulai kuzge kurene, ut \\
atsan da, baryber & tugel, yuk, nur bit ul! \\
batmamyn! & Paq ve saf, ap-ak kunelle \\
hem ulep, suyn toubende & ber fareshte, nur bit ul! \\
de cherep yatmamyn! & Tarta yash, dertle kunelne \\
Minde kouch, gayret ve & uz yanyna alga ul, \\
dert bar, kukregemde ut & Kin kolachlap min youzem \\
yana, & shunda, minemchoun Alla \\
Min kuremen alda - anda & ul! \\
yaltyragan ene!" & It looks like that, but no, \\
('No matter what waves & it's not a fire, it's the light! \\
you throw, I won't sink! & It's like some pure, inno- \\
And I won't die and rot & cent, bright-souled angel, \\
\hline
\end{tabular}

\begin{tabular}{|l|l|}
\hline under your waters! & and it's the light! \\
I have strength, sorrow, & It draws my young, pas- \\
and courage in me, fire is & sionate heart to itself, \\
burning in my chest, & That's where I swim to, \\
I see ahead - that's a bon- & For me it's God! [Sirin, \\
fire shines there!") & 1920, No. 40]. \\
\hline
\end{tabular}

Sirin, inspired by Tukay's ghazal "Bulmasa" ("If Not", 1908), created his own version of "If Not", (1920). Although the verse length of both poems is 15 to 15 , the poet's mentor chose a form of ghazal, while Sirin referred to qasida and mathnawi genres. In his poem, Tukay sings a psalm to one charming being that keeps the poet's heart beating, to the king of beauty - a nightingale; and Sirin, on the other hand, putting love in a political context, carries out the idea that the person who calls himself a Communist should care for and serve the interests of the people: "Bulmasa kunelde halykka mekhebbet hislere / Bulma communist, yakyn kilme buten uylar belen" ("If there is no feeling of love for the people in your heart / Then don't be a communist, don't even come close, bearing your thoughts") [Iakty iul, 1920, No. 41].

It's common knowledge that milestone anniversaries of G. Tukay's death have always set the literary community in motion. Sirin did not miss this opportunity and wrote his poem "Beznen Yashler" ("Our Youth") (as a response to Tukay's "Yashler") in honor of the tenth anniversary of the poet's death. Both are written in the genre of qasida, but the directions of Tukay and Sirin's thoughts are different: if the master's poem, written during the years of reactionary movements after the revolution of 1905, is imbued with depressive narration and despair for the future, the poem of Sirin, on the contrary, is filled with revolutionary romance that reflects the author's strong beliefs for the future. That is how Tukay portrays postrevolutionary despair and confusion: Bara millet zegyyf, abnyr-abynmas, / Sun yashlerde ut kabnyrkabynmas. / Kiche yakty ve milli ber kunelden / Bugen tychkan utyday nur tabylmas ("The nation goes weak, it stumbles, / The lights go off in youth before they even start, / From yesterday's bright soul of the nation, / A mouse-sized ray can't be found today.") [Tukay, 2011, p. 135]. Sirin's "Beznen Yashler" has a completely different pathos: the poet, inspired by the idea of building a new society, is optimistic: Yourekke ut kabyngan, menge sunmes, / Yana kukrekte dertler, hich suinmas. / Kouch aldyk, kaltyrau yuk yulibyzda, / Diyabez yashler: "Bu kukrek menge tunmas!" ("There's a fire in our hearts, it will never go out, / There's a passion inside our chest, it will never get 
cold. / We have gained strength, we have no trembling in our way, / We, the youth, say: "This chest will never freeze!") [Sirin, 1923]. The poem ends with an idea that is contrary to Tukay's thoughts: Kyzyl bayrak totyp bez yulga chyktyk, / Baryrbyz songacha, hichkem abynmas! "We took the red flag, then we hit the road, / We will walk till the end, no one will stumble!").

Sirin got acquainted with many art-driven young people during his studies at the Kazan Tatar Rabfak in 1923: he was in the same group with Musa Jalil. From 1923 to 1925, Sirin's sociopolitical and literary-aesthetic views underwent certain changes. Under the influence of that period's ideology, the poet opposed Islam and other religious teachings. His poems "Yelasynnar... Min Yelamyim" ("Let Them Cry... But I Won't Cry", 1923), "Ber Shayehnen Idealistic Logikasy" ("One Sheikh's Idealistic Logic", 1925), "Tynychlyk Koshlary" ("Birds of Peace", 1926), "Shuhrat" ("The Glory", 1929) criticized religious figures. The following passage from the "Birds of Peace" was quite popular during those years, some people would even make songs of it: "Allasy da kalmasyn, / Mullasy da chalmasyn / alyp tashlasyn! / Beznen kebek tir tugep, / Beznen kebek bil bougep, / eshlep ashasyn!" ("Let there be no God, / Let Mullah take his turban off! / Make him sweat like we do, / Make him bend like we do, / Make him work so he can eat!) [Sirin, 1926].

In due course, Sirin dived deep into Russian literature and began to imitate Mayakovsky, specifically for reading aloud in large audiences, thereby making a significant contribution to the development of a spoken word in Tatar literature. In his poem "Utly Heber" ("The Fiery Message", 1924) dedicated to Lenin's death (1924), he describes the entire population's grief over the death of the working class leader, and, along with channeling his parents' sorrow, he proclaims: "Kulak, mullalar bu ulemge shatlanmasynnar. Lenin yashi, Lenin - beznen youreklerde!" ("Kulaks, mullahs may not rejoice in this death. Lenin lives, Lenin is in our hearts!"). The same concept permeates his poem "Leninga Heykel" ("A Monument to Lenin") (1928), dedicated to the 4th anniversary of Lenin's death.

After graduating from Rabfak in 1925 and working at the "Sabanchi" newspaper for a year in Bugulma, Sirin came back to Kazan to enter the Eastern State Pedagogical Institute in the autumn of 1927. During his studies, he got acquainted with Kh. Taktash, G. Kutuy, H. Tufan, A. Iskhac, and others, and devoted all his efforts to his education and creative work. His undergraduate life (19261930) can be considered Sirin's years of introspection, both in life and in poetry.

Later in 1924, Sirin joined a literary society called "Sulf" (tat. "sul front", "Left Front"), founded by G. Kutui and G. Tulumbay. This fact from Sirin's life is mentioned in Akmed Iskhak's memoirs [Iskhak, 1987]. It is to be known that H. Taktash, G.Tufan, G. Kutui, K, Najmis, the people who Sirin was in constant communication with, conducted various experiments in poetry in an attempt to find their literary paths. In the same way, Sirin attempted to find new forms of his poetry in 1927-1928. In his works "Kunliler" ("They Are Jealous", 1927), "Beznen Kaygilar" ("Our Problems", 1928), he focused on the use of various complex characters and left poetic meaning behind. However, this venture did not last too long, and, in a year or two, he gave up his experiments with such matters.

During the wordsmith's student years, unexpected circumstances occurred: he was accused of resisting the Soviet authorities and went to prison in 1927. They locked him up in a solitary confinement for a whole month before releasing. After the incident, Sirin was frightened, and he would keep asking himself "When will they call me in again? Will I survive this?" Regardless of those circumstances, Sirin remained sincerely pro-party. Not willing to remain within the national framework, he studied the ideological and aesthetic achievements of Russian and world-wide poetry. As a result, the subject matter of his literary work expanded and the poet's self-esteem increased. His poems "Idenge toukermegez!" ("Don't Spit on the Floor!", 1928), "Kytai Jyry (Kytai shagyyre ShiKingtan)" ("The Song of China (From a Chinese Poet Xi-King)", 1928), and "Heine Fikere" ("Heine's Thoughts", 1929), echoing Mayakovsky's poetry, reflect Sirin's constant explorations and self-development.

Sirin sought to come up with his own style, his own genre in poetry and tried to achieve a perfect wholeness of his rhetorics and poetic forms. Following in Mayakovsky's footsteps, with the intention of reading his poems in large audiences, he strived to compose poems of decent forms and qualities of a spoken word. To achieve poetical expressiveness of his work, he used the following method - he pointed out each word, then explained their profound meanings and arranged them in a single row one after another. To a certain extent, it made the author delineate the internal rhythm of a poem and pick clear and accurate rhymes. His very 
first poems, "Enaler" ("Needles", 1922), "Teguche Kyz" ("The Seamstress", 1925) are good examples of Sirin's research on this method.

Apparently, the literary scholar G. Nigmati highlights this tendency in the poet's works. Regarding the role of literary devices in fine literature, he writes: “... In order to bring something into focus, the process of creating a word that phonetically imitates, resembles or suggests the sound that it describes - onomatopoeia -can be implemented. For instance, the falling and striking can be defined through simple and common words. They can also be expressed by using a set of sounds, resembling a collapse or a strike: it is called onomatopoeia. In Tatar poetry, this approach was used by poet Sirin many times" [Nig"məti, p. 108]. The author of the monograph, too, cites Sirin's poem "Teguche Kyz" as an example.

By using this very technique, Sirin creates his well-known poem "Yazgy Chechekler" in 1927. In this work, he chooses words that reflect the sound of drops, while, at the same time, conveying profound poetic meaning to the content of the work.

\begin{tabular}{|l|l|}
\hline Tam, & Yazgy tamgan \\
Tam, & Tamchylarnyn \\
Tamchy, tam, & Muzicasyn tynladym. \\
Tamuinny yaratam. & Shunar \\
Tamchy-Tamchy & Tamchylyanyp \\
Jyrlarynny & Tamdy \\
Ak kagazge taratam. & Kunelemdage uylarym. \\
& \\
(“Drop, & I listened to the music \\
Drop, & Of the drops \\
Raindrop, drop, & That dripped in spring, \\
I love it when you drop. & That's why \\
Drop-by-drop, & My thoughts inside of me \\
The songs of yours & Have started dripping.) \\
I scatter on a white paper. & [Sirin, 1959, p. 11]. \\
\hline
\end{tabular}

The poet not only chants the poetic beauty of the spring drops, but also, according to the demands of that epoch, connects this phenomenon with the form of existence in society, thereby enhancing the societal role of his literary artifice: Tam, / Tam, / Tamchy, tam. / Berge tamyik ichmasam! / Min de tamchylanyp tamyym, / Koureshlerde aksyn kan! (Drip, / Drip, / Drop, drip. / Let's drop together! / Let me drop by dripping too, / Let the blood drip during fights!) [Sirin, 1959 , p. 12]. With the publication of this work (1927), it quickly spread among the people, and even music was created for it. This melody has come down to present days and is now being sung in music lessons in kindergartens.
Using this technique, Sirin creates one of his dramatic monologues in 1929 - the philosophical poem "Minem Tragediyam" ("My Tragedy"), also known by its second title "Yourek Kani Belan", ("With the Blood of the Heart"). Sirin reflects on the personality of a true poet and their literary work, on the place of poetry, its mission, and its role in Soviet society. In this verse, permeated with the idea of striving for light and optimism for the future, he describes his own poetry as follows:

\begin{tabular}{|l|l|}
\hline Bu-minem & Yashise kile, \\
uylarym, & kup yashise. \\
Bu-ritm. & Kulese kile, \\
Bu-minem & kup kulese. \\
yuragem tibue. & Kilese kennernen \\
Bu-minem & kulgenen \\
kanymnyn & kurāse kile. \\
tanemnen & Ekh, \\
jyr bulip & Kurese! \\
kegazge & Kurese! \\
kuchue ... & Kurese!!! \\
& \\
These - are my & I want to live, \\
thoughts, & live long. \\
This is rhythm. & I want to laugh, \\
This - is my heart's & Laugh a lot. \\
beating. & I want to see \\
This - is how & the coming days \\
my blood & Laugh. \\
of my flesh & Oh, \\
is becoming & To see! \\
a song & To see! \\
on a paper. & To see!!! \\
& [Sirin, 1959, p. 6-7]. \\
\hline
\end{tabular}

Hence, the "Sirin style", novel and distinctive, appears in Tatar poetry in the 1930s. This is neither Taktash's style nor Hasan Tufan's style. Sirin's style, on the one hand, is imbued with a strong fantasy, deep hidden insights, lyricism, and revolutionary romanticism, while on the other hand, it is characterized by its resonant rhythm, quick-tocomprehend, plain, and eloquent language. By using a melody of words, the wordsmith manages to recite a variety of events and occasions. His poetry is predominated by musicality, which makes it reverberant, expressive, and at the same time, the author knows how to convey a profound meaning to the reader: he is constantly aware of public comprehension. He brings the concept of poetry and journalism together in a natural way.

Sirin and Taktash were close friends, they would always compete in poetic words with one another. During literary events, in the great halls of Kazan, both read their poems aloud and soon became favorite poets of the youth. In his essay, ded- 
icated to the poet's $100^{\text {th }}$ anniversary, Yamash Iganay proves this fact by quoting Sirin's own words: "Taktash would come out from one side of the stage, and I would appear from the other. As we start reading a poem, the audience would not know what to do, totally enchanted, plunging into the divine thrill, dazzling into the highest point of a magical and mysterious state", - he told me once in one of our meetings" [Iganay, 1996, p. 96].

Sirin and Taktash's friendship is reflected in their work too: there are many similarities and consonances in the poetry of the two compeers. As a matter of fact, they both created two different pieces of poetry on one topic or narrative. After all, it is not by chance that R. Mustafin called Sirin "The Rival of Taktash" [Medeni жomga, 1996]. For example: for the tenth anniversary of the October Revolution, Taktash dedicated his poem "Upkelim" ("I'm Offended") and Sirin' created "Uram Urtasynda" ("In the Middle of the Street"); in 1927, Taktash wrote the poem "Atly Sugyshchyga" ("To the Mounted Warrior") dedicated to the Red Cavalrymen, and Sirin wrote his "Atly Shlemnar". This kind of resemblance kept on living even when Taktash passed away. Speaking his mind on a new fashion for short dresses and skirts, he created "Jyrym Sina Bulsyn" ("Let Me Address My Song to You", 1927) and Sirin came up with his "Bala Itekle Ozyn Kulmekler" ("Long Dresses With Ruffles", 1933); inspired by falling snow, the former wrote his "Ak Chechekler" ("White Flowers", 1929), and the latter composed "Kyshky Chechekler" ("Winter Flowers", 1933); there is Taktash's poem "Lord Chamberlenge SSSR Krestyany hadi Taktashtan Jawap Notasy" ("A Response Note To Lord Chamberlain from the USSR Peasant Hadi Taktash", 1927) on international peace, Sirin has "Khalykara Sugyshka Karshi Kongressta Sirinnen Souylegen Berenche rechy" "'Sirin's First Speech at the International Congress Against War", 1933).

After graduating from the Pedagogical Institute in 1929, Sirin taught the Tatar language and literature at M. Vakhitov's high school. In 1930, he was offered a position of editor in chief in the department of agriculture at Tatizdat. He worked there until August 1935, that is to say, until his arrest.

Sirin's poetry of 1930 to 1935 brings the most relevant topics of the epoch to focus. His very famous large-scale "Bulmyi! Bulmyi!" ("It Won't Happen! It Won't Happen!”, 1930) focuses on the topical issue of those years - agricultural collectivization. The idea "Build a Life of Industrial Collectivization" is explained by the author through an- tithesis: the old-fashioned life based on private estate is opposed to the new society, the new life based on public property. The poet explaines to his countrymen the superiority and benefits of collective life in simple words. He uses the verse "Ashlygynny jilgeremsen, jilger, jilger" ("You are milling your grain, mill, mill") as a refrain, thus, the more it recurs, the deeper goes its meaning. This work was very popular in those years, and was even recited on the stages. For example, this poem was in a prominent repertoire of Mokhtar Mutin.

In order to circulate decrees of the $16^{\text {th }}$ Congress of the Communist Party in public, without any deviation from "the beacons" of Lenin, Sirin wrote his "Kup Tarat" ("Spread A Lot") in 1930. The poem "Tatarstan" (1930), dedicated to the $10^{\text {th }}$ anniversary of the Republic of Tatarstan, depicts a first-person narrator who rejoices in the success of the region. Sirin describes a student's lifestyle in his poems "Mikroskoply Kuzler" ("Eyes with Microscopes"), "Koirykly Student" ("A Student with a Tail"); the topic of youth and love in "Kash Ostynnan" (“A Frown”), "Uzbek Kyzy 'Derdem Bar'ga" ("To the Uzbek Girl 'Derdem Bar"'), "Boshlygynnyn Zenger Kikrigen" ("Your Hat's Blue, White Comb").

He published his small picture books for children "Kouz" ("Autumn", 1929), "Kysh" ("Winter", 1929), "Yaz" ("Spring”, 1929), “Jey" ("Summer", 1929), "Keshe" ("A Human", 1930), "Be-e-e de me-e-e" (1931), "Korych Atlar" ("Steel Horses", 1931), "Timer Yul" ("The Railway", 1931), "Tramvaylar Nik Tuktagan?" ("Why Did the Trolley Stop?", 1932), "Jilek Bakchasy" ("A Strawberry Meadow", 1933), and in 1931, released quite a large collection of poems called "Tamchylar" ("Raindrops") [Shəripov, 2017, p. 329].

His poem "Zenger Kouzle Jeget Yuk Inde" ("The Boy with the Blue Eyes is Gone Now"), written in the grief of Taktash's untimely death in 1931, is an expression of the devastation Sirin experienced after this tragedy, his heavy pain: Yofraklarga uen beylep yourgen / Kouchle shagyyr / bugen kumelde. / Tambov urmany kuk / Shaulap usken / Bouiek talant khezer yuk inde (A powerful poet, / Who used to tie his thoughts on leaves / was buried today. / Who grew up noisy, / Like Tambov forest, / A great talent now is gone.) [Meidan, 2015, No. 12, p. 30]. Although the poet died, the narrator sincerely believed in his undying art, that it would live forever: Ni souilisez, / Shagyyr ulemeni? / Ul bit teli berge yasherge. / Ilebeznen 
kouchle ber talantyn / Nik kildegez / Monda kumerge? ("What nonsense, / Do poets really die? / All they want is to live together. / Why did you even come / To bury here / One big talent of our country?") [Meidan, 2015, No. 12, p. 31].

However, in the 1930s, Sirin, who sincerely believed in socialist reforms, developed the feelings of suspicion and doubt towards the new society: he was worried about social injustices and sought to unravel their cause. He, a genuine patriot of the Soviet society, wanted to understand why he was being persecuted and accused of crimes he had not committed. Gradually, he realized that inside the Soviet system, shod with red slogans, there was guile, deception, abuse, corruption, and that he was now forced to live inside this system. The poet's rebellious heart, once filled with the joy of freedom and independence, was now loaded with hatred towards such hypocrisy and treachery: his loathing of injustice, rooted in his madrasa years, reached its highest level. It was a turning point of his poesy: he put the injustices and hypocrisy in the hot flames of satire. By referring to the Aesopian style, he hid this negative phenomena within the parable genre: "Keje belen Saryk" ("The Goat and the Sheep", 1931), "Satuchy hem Satyp Aluchy" ("The Seller and the Buyer", 1932), "Karga Belen Saieskan" ("The Crow and the Magpie", 1934), "Ishek Belen Kuyan" ('The Donkey and the Rabbit', 1935), etc. Moreover, his "Bala Hem Houkumetler" ("Children and Governments" 1932), "Tormysh Yaryna Basyp" ("Standing on the Edge of Life", 1933), "Kounelle - Kounelsez" ("Happily and Sadly", 1933), "Kem Bele, Kem Belmi" ("Who Knows and Who Doesn't", 1935) criticized the armament of the countries and the suppression of human freedom by the political order. After spending some time in the NKVD probationary ward, he wrote his " 'Sin Koida Buldyn?' - Diyuchelerge" ("To Those Who Ask Where I Was", also known by the title "Min Kaida Buldym? - Min Shunda Buldym!", dated "29/VII 33" ). There, he boldly described his life spent in a solitary confinement through vivid colourful details: "Min buldym shunda, kaidadyr shunda / Sandugachlar oya yasamy. / Min buldym shunda, kaydadyr shunda / Chypchyklar da kelep sairam ... / Buldy kounnerem, bette ounnerem / Ber sYz souylesherge жоudжоudem. / Irekte yourgen, matur koun kyrgen / Chebennerney kounen kounledem." ("I was there, somewhere / Where nightingales don't nest. / I was there, somewhere / Where sparrows don't come to sing ... / Once I lived, now my days are gone / Dying to say one single word, / I envied the life of flies / That lived in freedom, having beautiful days") [Sirin, 2015, No. 12, p. 46].

Bleak future, insecurity, and constant fear of being taken away any minute made Sirin bear the brunt of it: he even brought up the question of death to his poetry. He expressed his heart's tragic state, the collision of feelings through the poem "Khis" ("A Feeling", (September 29, 1933)) as follows:

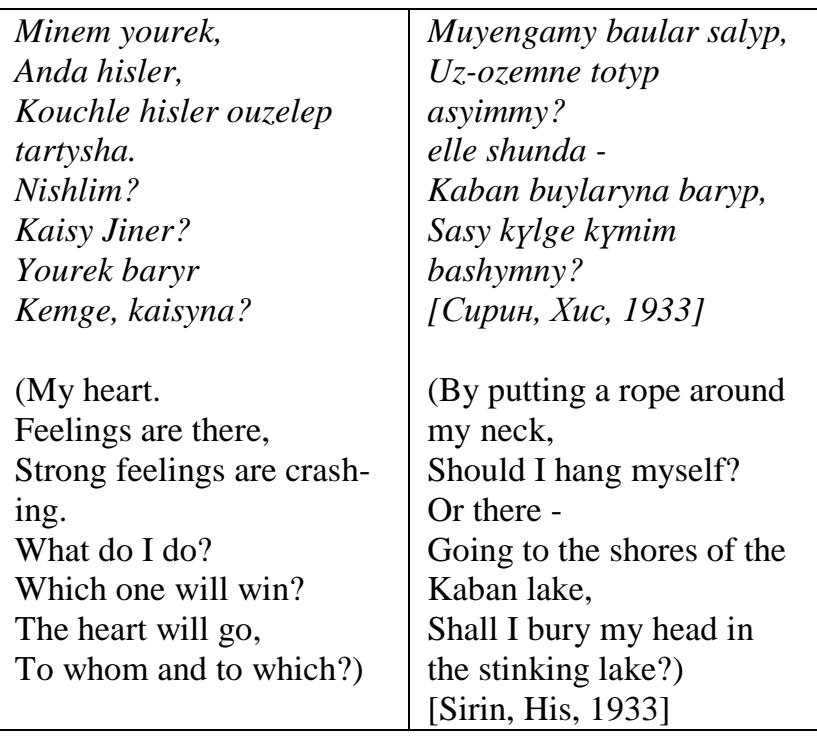

The poetic narrator, who is close to the author himself, calls Azrael: Ey, Ejel! / "Matur" ejel! / Kilche ele minem karshyga! / Kilche, beg'rem, / Souy sin mine, / Bulchy minem karchygam! (Oh, Azrael! / "Beautiful" Azrael! / Come and meet me! / Come on, darling, / Love me, / Be my old wife!) [Sirin, His, 1933].

Preoccupied with suicidal thoughts, he got very close to taking his life. In his poem "Khushygyz!" ('Farewell' is another version in "Kysh Sairamyi Sandugach", November 23, 1934) he says: "Khushygyz, ey duslarim, / Dus-ishlerem, hush, min kitem. / Menge de koytmam inde, / Kureshmebez inde buten. I Ut tourtem taudai teleklerge, / Jan souigen eshlereme. / Chik kuyam antym belen min / Dourlep torgan hislereme". ("Farewell, my friends, / My pals, goodbye, I'm leaving. / I will probably never come back, / We will probably never see each other again. / I'm setting fire on dreams of the size of mountains, / To the work of my life. / I draw a line with my oath / To my swaying feelings"). The poem ends with words: "Khushygyz, tallar, yukeler, / Khushygyz, ey, olmagach! / Kicheregez shag'yr Sirinne, - / Kysh sairamyi sandugach ("Farewell, willows, maple trees, / Farewell, oh, the apple tree! Forgive 
poet Sirin, - / But the nightingale doesn't sing in winter") [Sirin, 1934, 23 noiabr].

Enriching his poetic work with new techniques and literary devices, Sirin made use of the letter and telegram forms. His poem "Lermontovtan Hat" ("A Letter from Lermontov", 1933) is written on behalf of Lermontov, in it he narrates: Chynbarlykny dounyada souiylerge / Moumkinme ele? .. Ber khat salygyz! .. ("Is it still allowed / to speak the truth in this world?.. / Send me a single letter!..[Sirin arhivy, 1933]. His epistolary poems "Tukaevtan Siringe Telegram" ("A Telegram from Tukaev to Sirin"), "Tumagan Balalardan Khat" ("A Letter from Unborn Children"), "Bouten Doun'yaga Telegram" ("A Telegram to the Whole World") are also written in the forms of a letter and a telegram.

Despite such threats in his life, Sirin still maintained an optimistic spirit. "Shefkat Tutashy" ("The Nurse", 1930), "Pushkinnan Ber Ouzek" ("An Excerpt from Pushkin", 1934), "Karly" ("It Is Snowy", 1934) are all penetrated with the hope that "these hard times would pass". In his work "Karly" he wrote: "Ih-ma! Ele de ouzebez chydam, / Yourek koungen kaygy-hesretke. I Yuksa beznen bashny elle kaychan / Shashtyryrlar ide hesretler." ("Oh! We are still patient, / Even if our hearts are in distress. / Otherwise, they would drive us crazy, / Those sorry wretched people".)

In search of consolation, he explored RussianEuropean and Oriental poetry, looking for motifs that resonated with his spiritual state. He created the poems "Gejeplenu (Abel Galeh alMagarriden)" ("Fascination (from Abel Galeh alMagarri)", 1933), "Altyn Metal (Shakespirdan)" ("The Golden Metal (from Shakespear", 1933), "Zenger Kichte" ("In the Blue Evening") inspired by Esenin, and "Alsu Jaket, Zenger Kuzler" ("A Scarlet Jacket and Blue Eyes", 1934). "Altyn Metal (Shakespirdan)" and "Katorzhannar" ("The Convicts", 1933) criticize the fact that many things in society are built with money. He wrote his poems "Sin Bit Gulsem Tugelsen" ("You are not Gulsem", 1933) and "Auchylar" ("The Hunters", 1934), based on the literary works of the French poet and satirist Pierre-Jean de Bérange (1780 1857), and devoted to the subject of morality. Along with their sardonic, hidden meanings, the events, depicted in these poems, reveal the treachery that became a stable attribute of the era the poet lived in.

Sirin not only created lyrical poems but also many epic ones. His "Keshe" ("Man", 1930), "Halykara Sugyshka Karshi Kongressta Sirinnen
Souilegen Berenche Reche" ("Sirin's First Speech at the International Congress against War", 1933), and "Ana" ("Mother", 1934) are written in this format. The poem "Keshe", addressed to children, portrays the Men of the nation, as being stronger than the most fearful wolves. The opening part of Sirin's rhetoric poem "Sirin's First Speech at the International Congress against War" describes Sirin's views on peace and disarmament. Then he switches to the issue of government and personal identity. His refrain "Deulet ouchen kesheler yashime? / Keshe ouchen melle deuletler? / Keshe ouchen deuletler yashese, / Nige bolai beznen bu eshler?" (Do people live for their country? / Are countries really meant for people? / If countries are for people, / Then, why are we doing so bad? ) [Sirin, 2019, p. 91] criticizes the government policies that are aimed to suppress freedom of the masses. At the end of the poem, Sirin speaks out against greed and hypocrisy, and defends those who follow their humane ideas.

Sirin's epic poem "Ana" ("Mother") was one of the reasons why he was repressed. He wrote that Stalin's decree "As socialism prevails, so does the class struggle in society", inflaming both brotherhood and kinship, also causes great misfortunes and tragedies. The story is being narrated by the mother's son. Political views and class struggle place the mother and the son on two opposite sides. The mother, who has raised thirteen children, has been evicted from her house, accused of having two or three cows; she is left to beg for the money on the streets. The mother addresses her son on the street and begs for mercy. However, her son, strongly devoted to the ideas of the revolution, shows cruelty: he considers his mother to be a class enemy and refuses to help her responding to his mother with these words:

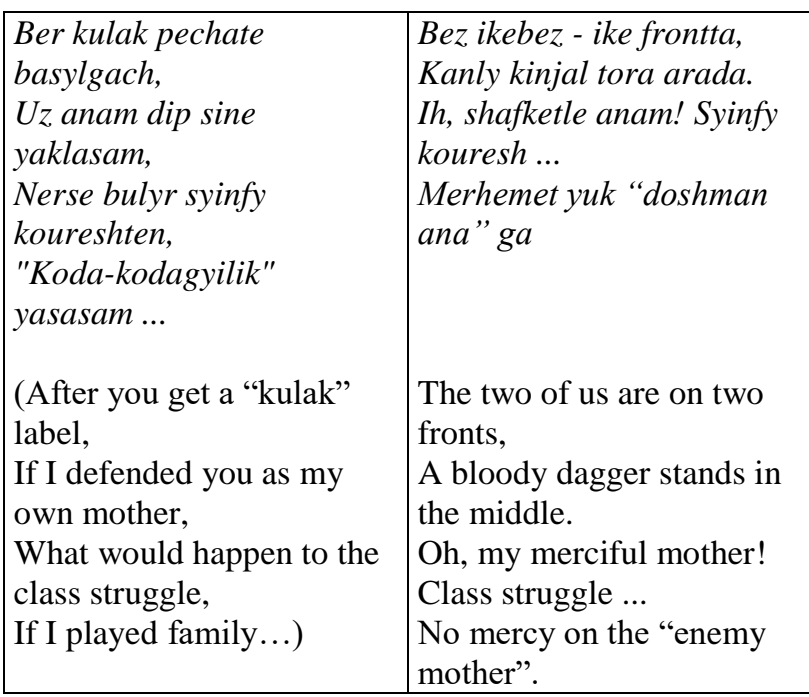


The mother's words clearly reflect the fearful atmosphere of that time. While she was standing there and wailing in self-pity, her newborn baby died in her arms. Clearly, the poem shows to the reader how cruel and inhumane the class struggle of the 1930s was. It would be difficult to find another work of such tragic depth on this subject in the history of Tatar poetry.

In the Writers' Union, the attitudes towards Sirin, who had been tagged with unjust labels, were also far from being favourable. R. Mustafin wrote: "By accusing Sirin of "ideological intolerance", they won't let Sirin become a member of the Writers' Union, blaming him for his "formalism" and other "ism"s. These incompetent poets are being judged by their "ideological views" and keep getting published, rewarded, and promoted" [Mostafin, 1996, p. 163].

Knowing his place in poetry, sharp-tongued Sirin responded to such humiliation with bitter satire. He called the Writers' Union in Kazan "a horse comedy". In his poem "Let's Raise the Glasses!", he criticizes the members of the Writers' Union and describes how people are being drawn to drinking by a complicated life and exhaustion.

The poem "Paganini" (1935) is also imbued with the idea of exposure: Paganini bezde yuk ul, / Bulsa da, anar dounya tar. / Paganini bulmasa bit, - / Poganyilar bezde bar (We don't have a Paganini here, / If we did, then the world would become too small for him. / Even though there's no Paganini, / There's "Poganyilar" (rus. rotten)) [Meidan, 2015, No. 12, p. 81]. The rulers of the Soviet society, who were used to being positively described, could not approve of such a word choice as "rotten" and this mockery at their drawbacks. This poem was another reason for Sirin's conviction. The poet is also believed to have composed a sarcastic epigram on Stalin himself. Although no trace of this publication has been found, Bulat Sultanbekov's article contains some of its content: "It says, "My nightingale, in every song of yours, praise Stalin. Then they would notice you and reward you with "Nightingale Honored by the Soviet Union" title."

Sirin was arrested on August 22, 1935, and he was sentenced to five years of prison in Siberia.

\begin{tabular}{|l|l|}
\hline Bakchalarda basyp & Akcharlagym, jey kanatyn, \\
yourgen ezem kaldy, & kil yanyma, \\
Enkey, sina bik kyp souller & Selam khatlar yazyim ap- \\
suzem kaldy. & ak kanatyna. \\
Sau bul, enkey, tenem kitte, & Sandugachym, sin tynych \\
janym kaldy, & bul, saura, irkem, \\
\hline
\end{tabular}

\begin{tabular}{|c|c|}
\hline $\begin{array}{l}\text { Jannan artyk kurgen } \\
\text { yarym, kanym kaldy. }\end{array}$ & $\begin{array}{l}\text { Min Ireknen kadren belem, } \\
\text { sina timem. }\end{array}$ \\
\hline $\begin{array}{l}\text { (My footprints are left in } \\
\text { gardens, } \\
\text { Mother, so many words are } \\
\text { left untold. } \\
\text { Good-bye, mother, my } \\
\text { body is gone, my soul re- } \\
\text { mains, } \\
\text { Dearer than the soul, my } \\
\text { blood remains.) }\end{array}$ & $\begin{array}{l}\text { (My seagull, spread your } \\
\text { wings, come to me, } \\
\text { Let me write letters on } \\
\text { your snow-white feathers. } \\
\text { My nightingale, don't wor- } \\
\text { ry, sing, dear, } \\
\text { I value freedom, I will } \\
\text { never hurt you). [Meidan, } \\
2015, \text { No.12, p. } 45] \text {. }\end{array}$ \\
\hline
\end{tabular}

- writes the poet about departing from his motherland. A similar motif of tough, dramatic feelings, and emotions appears in his "Oustelemde Ber Stakan Chei Kaldy, Echelmede" ("A Cup of Tea Was Left on My Table, Untouched"), "Yashlegem Yashke Buyalyp" ("My Youth Painted in Tears"), and "Muncha Tashy" ("Bath Stone").

Unbearable living conditions completely tired up and exhausted those exhiled. They received 250 grams of bread per day, and if they failed to fulfil their daily plan, it would be taken away from them. The poet was in a railway construction there. With every sunrise, there came a cruel fight for life was on them. Unable to deal with insufferable hardships, many people died there. Sirin, who had a love for life and strong willpower, did not succumb to humiliation and starvation, he survived. The memoirs of his life in exile say the following: "Many years have passed. There was no flesh or blood left in my body. If I cut my hand with a knife, red blood wouldn't come out, but some yellowish water would appear; if there was a minor injury in your body, due to the lack of tools, it wouldn't heal for years".

Finally, after a five-year prison term had passed, Sirin was released and returned to his homeland in the fall of 1940 . He was really tired, exhausted, his clothes were completely worn out. Only after changing his clothes in his brother Shamil's place in Bugulma, he finally returned to Karakashly. After a short break, he voluntarily left for the Great Patriotic War in 1941. He participated in battles near Moscow. In the fall of 1942, because of a concussion, he returned to the village to spend the winter in his hometown. When he recovered, he joined the kolkhoz (rus. a collective farm): there he looked after horses, carried hay across the field, retained snow in the fields. It was during this time when he wrote "Kar Totkanda" ("While Preserving Snow", 1942). In this poem he praises a 
peaceful life, a process of working in the embrace of nature.

Sirin returned to the front in the spring of 1943. By the end of the year, with serious injuries, he was sent to Tashkent hospital. After his recovery, he went back to Karakashly, and once again put all his efforts into working in the kolkhoz. For his heroism during the war, he was honorod the medals "For the Victory over Germany in the Great Patriotic War 1941-1945", for his service in the rear "For Valiant Labour in the Great Patriotic War of 1941-1945", and the Jubilee Medal "Twenty Years of Victory in the Great Patriotic War of 1941-1945".

Sirin moved to the Bavlinski district centre, Akbua township, in 1946. After completing a oneyear beekeeping course, he worked in Karakashly and Tashkichu villages as a beekeeper.

Even after his come-back from the exile, Sirin's literary activity did not come to an end but it became a little dull, and his former straightforwardness softened. The poet could not bring his "Sirin style" back to life but started writing in a traditional way. In this period, he created more than 90 lyrical poems, one epic poem, and many fairy tales. A few years later, the poet's health deteriorated: on top of having colds in the exile, being wounded and having a concussion in the war, he gots sick with tuberculosis. However, he did not drop his quill. In 1962, after his illness got worse, he was forced to go to the Akbua tuberculosis dispensary.

The pain of five years of exile, the wounds from the war could not break Sirin's spirit. He continued to condemn injustice, "redness", which still existed in the Soviet society in the period from 1940 to 1969 . To extend the ridicule, he used such allegories as "a socialist whistle" in "Kart Bolshevik, Militsioner hem Kyzyl Sybyzgy", 1952) and "a socialist tree" in "Matur Khatyn" ("A Beautiful Lady", 1956). He dedicated his parable "Shatlykly Ulem" ("The Rejoiceful Death", 1953) to Stalin's death. His other parables "Ayu Belen Kouzge hem Min" ("The Bear with a Mirror and Me", 1944), "Bal Belen Balan" ("Honey and Viburnum, 1945), "Keje belen Saryk" ("The Goat and the Sheep", 1958), "Ike Urdek" ("Two Ducks", 1960), "Doureslek hem Keje" ("The Truth and the Goat" 1961), "Kyskartuga Elekkenner" ("Under Redundancy", 1961), "Kygerchen, Karchyga hem Keshe" ("The Pigeon, the Hawk and the Man", 1964) are aimed against people's greed, selfishness, ignorance, cowardice, and national seclusion.
In the case of "Kyskartuga Elekkenner", for example, a figurative horse, rabbit, and dog are having a conversation: all three of them were made redundant and fired. They ask each other "Why were you laid off?" The Horse's reply is: "My fault is that I did my job right, not caring about what the others did, and not taking part in stealing. The owners identified me as an enemy when I didn't steal together with the others". The rabbit says: "The owners found out that I was a coward, so they thought "Even if we fired him, he wouldn't say a word". And the dog's answer was "I wasn't to my owners' liking. I didn't know how I lived working for the rich. As it turned out one day, instead of wagging my tail, I mistakenly barked". Apparently, the answers of all three sounded like bitter satire on the habits of Soviet society, they proved the poet's spiritual resilience even in that period.

New topics occurred in Sirin's poetry in 1941 to 1969: the issue of war ("Vanyusha Belen Katyusha" ("Vanyusha and Katyusha"), 1943, "Khurlykly Isem - Kolonizator" ("The Shameful Name - Colonizer", 1960), "Beznen Burych" ("Our Duty", 1961)); criticism of superstitions and gossip ("Don'ya Betmi Menge de" ("The World Never Ends", 1961)), the pride of Yuri Gagarin's flight to space "Kukler Kapkasy Achyk", ("The Gates of the Sky are Open", 1961); denounciation of the dictatorship "Kantsler Adenauer Hem Shagyyr-Doctor", ("Chancellor Adenauer and the Poet-Doctor"), criticizing the ugliness and inhumanity hidden within beauty (a poem "Matur Khatyn" ("A Beautiful Lady", 1956)), etc.

In 1958-1959, Sirin made a significant contribution to the development of Tatar children's literature, which requires great creative literary skills. His works cover a variety of topics and serve to instill a decent sense of morality and a sense of beauty: on the importance of school, education, and upbringing ("Kire Malay" ("A Naughty Boy", 1942), "Ana belen Bala" ("The Mother and the Daughter", 1948), "Neni Orator" ("A Little Orator", 1951), "Biek Baskych, Komesh Achkych" ("A High Stairway, a Silver Key", 1958), "Belem Tavy" ("The Mountain of Knowledge", 1960), etc.); the topic of youth and love ("Temle Uilar, Dertle Hisler belen" ("With Sweet Thoughts and Passionate Feelings", 1943), Yeget belen Kyz ("A Young Man with a Girl", 1956), etc.); Rural life, the lifestyle of the villagers, their customs, various other natural phenomena are described in his "Yaz Kounnere. Yangyrly Koun" ("Springtime. A Rainy Day"), "Alladan Syyer Sorau yaki Elekke 
Kurshelek" ("Asking God for a Cow, or Good Old Neighbourship"), "Ike At" ("Two Horses"), "Kuche Torgan Inesh" ("A Moving Stream", 1945), "Yugalgan Saban" ("The Missing Plow", 1951).

The craft of beekeeping, which once became a hobby of his life, rose to poetic heights, and is described in poems "Umyrzaya hem Bal Korty" ("The Snowdrop and the Bee"), "Zur Kunak" ("The Great Guest"), "Kortlar Shehere" ("The City of Bugs"), "Bal Babay" ("The Honey Grandfather"). Sirin, following in footsteps of folk songs, wrote poems imbued with subtle humour: "Kyzlar Jyrlyilar" ("The Girls Are Singing"), "Yana Kyrlar" ("Lands Are Burning"), "Ey, Alym Sin, Goulem Sin!" ("Oh, You're My Scarlet, You're My Blossom"). To criticize such qualities as greed and hypocrisy, he created his fairy tales "Ber Muzhik, Ouch Pop" ("One Man, Three Popes") and "Maktauly Burek" ("The Vaunted Hat") in the form of prose in the 1960s.

Upon returning from the exile, Sirin, probably in search of an adherent of his ideas and a peace of mind, resumed his former friendship with Hassan Tufan. They corresponded with each other and even paid visits to each other's houses. At one of those meetings, Hasan gave Sirin his book, issued in 1958, "Songs. Poems", signed with the following meaningful words in green ink: "Sirin! May this be the reminder of our unparalleled beautiful days of living your life for the second time around. Yours respectfully, H. Tufan. 27. XI. 61'. In one of Sirin's letters (November 6, 1961), the following lines can be found: "Tufan!.. Are you back safe and sound? It was quite frustrating for us to see you off. We felt so lonely...". Accordingly, $\mathrm{H}$. Tufan was in Bavly, visiting Sirin in the autumn of 1961 (at that time Sirin lived in the "SMU-4" borough of Bavly, in one of the rooms of Barrack No. 5).

As it was stated earlier, Sirin spent his last days suffering of tuberculosis. In one of his latest works, "Ber Kisek" ("One Piece", 1964), the poet continued to describe his plans for the future: Teleklerem chiksez minem, hisapsys; / Yourek tibulerem sanly, hisaply. / Isep-hisap eshlerem kup nichakly, / Tende janym kunak, belmim, nichakly? ("My wishes are limitless, countless; / My heartbeat is limited, counted. / I have to do lots of accounting, / My soul is a guest in my body, and I don't know for how long.") [Sirin arhivy, mashinkada basylgan tekst].

Poet Sirin passed away after a long and serious illness on November 23, 1969, in Bavly, and was buried in the city's Tatar cemetery. During the celebration of the writer's $90^{\text {th }}$ anniversary, a large memorial stone with Sirin's bas-relief was placed on his grave by the administration of the Bavlinsky district. There are streets named after Sirin Batyrshin in Bavly, the Yutazinsky regional centre - Urussu, and in Karakashly village. This is how the memory of the poet, who devoted his entire life and talent to the cause of bringing justice back to society, keeps on living. Sirin's poetry is a historical chronicle of the complex and contradictory Soviet reality. It depicts political, economic, literary, cultural changes, and dangerous events that happened in the country after the October Revolution of 1917, expressing the dramatic and tragic experiences of his lyrical hero.

\section{References}

Amir, M. (1935). Sovet adabiiaty [Soviet Literature]. No. 12, pp. 66- 68. (In Tatar)

Bedig, H. (1932). Iaḩalif. No. 9- 10. (In Tatar)

Baian, N. (1934). Kazan utlary [Kazan Lights]. No. 1- 2. (In Tatar)

Gabdulla Tukay (2011). Әsarlar. Akademik basma. [Works. Academic Publication. In Six Volumes]. T. 2. 384 p. Kazan, Tatar. kit. nəshr. (In Tatar)

Gali, Z. (1931). Sirin шигырьләре [Sirin's Poems]. Ianalif. No. 4, pp. 51- 54. (In Tatar)

Gali, G. (1934). Iap̧a baskychka [To the New Stage]. Kazan utlary . No. 1-2. (In Tatar)

Galimæçan Nigmati: tormyshy iazmyshy fanni metodik eshchanlege (2018) [Galimzhan Nigmati: Scientific and Methodological Activities in His Life and Destiny]. Galimжаn Nigmati. T. Sh. Gyilaжev redaktsiiasendə. 252 p. Kazan, "Brig" nəshr. (In Tatar)

Galimullin, G. (2015). Kalamennən tamdyryp kanyn... [Dripping His Blood from His Quill...]. Məidan. No. 12. (In Tatar)

Galimullin, F. G. (1998). Estetika həm sociologizm: 20-30 nchy ellar tatar adabiyatynda estetika kanunnaryny ham sociologizm talopləreneң yzara monasabate [Aesthetics and Sociology: The Relationship between the Laws of Aesthetics and the Requirements of Sociology in Tatar Literature of the1920s and 1930s]. 223 p. Kazan, Məgarif. (In Tatar)

Ialkynly ellar poeziiase (1968) [Poetry of the Fiery Years]. Tez. S. Mortazin. P. 169. Kazan, Tatar. kit. nəshr. (In Tatar)

Igənəi, Ya. (1996). Ez syzyp atylgan joldyz [A Shooting Star]. Argamak. No. 12, p. 96. (In Tatar)

Iskhak, Ә. (1987). Balakai genə ber istalek [Just a Little Memory]. No. 3, p. 6. (In Tatar)

Iunysov, A. (1996). "Kysh sairamyi sandugach" ["The Nightingale Doesn't Sing in Wnter"].Vatanym Tatarstan". 20 dekabr'. (In Tatar)

Latifullin, M. (1959). Shigyr'lar [Poems]. Sovet Tatarstany. 9 dekabr' (In Tatar) 
Latifullin, M. Sirin həm апyң poeziyase [Sirin and His Poetry]. (Mashinkada 22 bit. Sirin arhivynda saklana). (In Tatar)

Mostafin, R. (1996). Taktashnyң kondoshe [The Opponent of the Board]. Mədəni жomga. 3 mai. (In Tatar)

Mostafin, R. (1996). "Kysh sairamyi sandugach" ["The Nightingale Doesn't Sing in Winter"]. Kazan utlary. No. 12, pp. 161 - 164. (In Tatar)

Nəжmi, K. (1935). Sovet adəbiiaty [Soviet Literature]. No. 11, pp. 72- 75. (In Tatar)

Nig"məti, G. (1930). Sovet adabiiaty [Soviet Literature]. No. 4. (In Tatar)

Nig"məti, G. (1931). Utyz berenche elga kerganda ( Odabiyat ham уаңа kөchlar) [Entering the Thirty-First Year (Literature and New Forces)]. Іаңalif. No. 1, pp. 34- 38. (In Tatar)

Redaktsion mokala (1987) An Editorial Article. Kazan utlary. No. 2. (In Tatar)

Sabirov S. (1986). Davylly ellar жyrchysy [Singer of the Stormy Years]. Hezmətkə dan. 13 dekabr'. (In Tatar)

Səifi-Kazanly, F. (1930). Iay̧alif . No. 1. (In Tatar)

Sirin. (1920). Dimgezga [To the Sea]. Iakty iul. 25 noiabr' (No. 40) (In Tatar)

Sirin. (1923). Hazerge yash'lar [Modern Youth]. Tatarstan. 15 aprel' (In Tatar)

Sirin. (1926). Tynychlyk koshlary [Birds of Peace]. Sabanchy. 24 mai. (In Tatar)

Sirin. Tamchylar [Drops]. Keresh syz avt. Z. Gali. Kazan, Tatizdat, 1931. 60 б. (In Tatar)

Sirin. (1933). Kyshky chachaklar [Winter Flowers]. Sovet adəbiiaty. No. 12. (In Tatar)

Sirin. His, 1933 el. NKVD arhivynnan M. Latifullin algan shigyr' [His, 1933. From the NKVD archive. A poem by M. Latifullin]. (Sirin arhivynda saklana). (In Tatar)

Sirin. Lermontovtan hat, 1933 el. NKVD arhivynnan M. Latifullin algan shigyr' [A Letter from Lermontov, 1933. From the NKVD Archive. A poem by M. Latifullin]. (Sirin arhivynda saklana). (In Tatar)

Sirin. (1934). Karly [It's Snowy]. Sirin arhivy, mashinkada basylgan tekst. (In Tatar)

Sirin. (1934). Hushygyz! [Farewell!]. Sirin arhivy, mashinkada basylgan. 23.11.1934. (In Tatar).

Sirin. (1959). Shigyr'lar [Poems]. Meh. Z. Mansur. 54 p. Kazan, Tatar. kit. nəshr. (In Tatar)

Sirin. (1968). Achlar tavyshy [The Voice of the Hungry]. Ialkynly ellar poeziiase [Tez. S. Mortazin]. 169 p. Kazan, Tatar. kit. nəshr. (In Tatar)

Sirin. (2015). Shigyr'lar, proza asarlare. Shagyjr turynda makalalar, istaleklar [Poems, Prose Works. Articles and Memoirs about the Poet]. Məidan. No. 12, pp. 3-97. (In Tatar)

Sirin. (2016). Tormysh hatiralare [Memories of Life]. Kazan utlary, No.12, pp. 130-160. (In Tatar)

Sirin. (2019). "Halykara sugyshka karshy Kongress"ta Sirinneu sojlagan berenche reche [Sirin's First Speech at the International Congress against War]. Bezneң miras. No. 11, pp. 90-92. (In Tatar)
Sirin. (2020). “Ana” poemasy [The Poem "Mother”]. Bezney miras. No. 8, pp. 68-69. (In Tatar)

Shəripov, Ә. (1976). Yzencholekle shagyir' [An Unusual Poet]. Socialistik Tatarstan. 5 dekabr'. (In Tatar)

Shəripov, Ә. (1986). Tribun shagyir' [A Tribune Poet]. Socialistik Tatarstan. 7 dekabr'. (In Tatar)

Shəripov, Ә. (1997). Shagyir' Sirin: tormyshy ham iæçaty [Poet Sirin: Life and Works]. Fən həm məktəp. No. 2, 3. (In Tatar)

Shəripov, Ә. (1998). Sirin faжcigase [Sirin's Tragedy]. Tatarstan. No. 2, pp. 78-92. (In Tatar)

Shəripov, Ә. (2006). Shagyir' Sirinnеy tormysh ham iæçat iuly [Poet Sirin's Way of Life and Literary Works]. G. Tukainy tuuyna 120 el tuluga bagyshlangan fənni-gaməli konferentsiia materiallary. Yar Chally, pp. 81-89. (In Tatar)

Shəripov, Ә. (2011). Kalamnan tamdyryp kanymny [Dripping my Blood from My Pen]. Tarihi-mədəni miras. No. 1, 2. (In Tatar)

Shəripov, Ә. (2007). Sirin shigyr'lare [Sirin's Poems]. Məidan. No. 3, pp. 99-108. (In Tatar)

Shəripov, Ә. (2014). Jerək kany belən iazylgan [Written in the Blood of the Heart].Bezney miras. No. 7, pp. 54-61. (In Tatar)

Shoripov, Ә. (2016). Shig"riiatto Sirin stile [Sirin Style in Poetry]. Kazan utlary. No. 1, pp. 138-145. (In Tatar)

Shəripov, Ә. (2016). Sirin Batyrshinnyщ tuиyna 120el [On the $120^{\text {th }}$ Anniversary of Sirin Batyrshin]. Kazan utlary. No. 12, pp. 128-129. (In Tatar)

Shəripov, Ә. (2016). Tormysh hatiralare [Memories of Life]. Kazan utlary. No. 12, pp. 130-160. (In Tatar)

Shəripov, Ә. (2016). Sirinnę Tukaiga shig"ri жçavaby [Sirin's Poetic Response to Tukay]. Məidan. No. 4, pp. 57-62. (In Tatar)

Shəripov, Ә. (2016). Shagyir' Sirinney "Ana” poemasy [Poet Sirin's Poem "Mother"]. Islam həm torki den'ya: Məgarif, tel. ədəbiyat, tarih həm din problemalary: VIII Halykara Tyurkologiya konferentsiiatse materiallary жyentygy (Rossiia, Tatarstan respublikasy, Alabuga, 2016 el, 22 aprel') / жav. mөh. A. Z. Nigamaev. Kazan, Kazan universitety nəshriiaty, pp. 157-159. (In Tatar)

Shəripov, Ә. (2016). Gazaply ellar asha [Through the Years of Pain]. Mədəni жomga. No. 48-49. (In Tatar)

Shəripov, Ә. (2017). Sirin. (1896-1969) [Sirin. (1896-1969)]. Tatar ədəbiiaty tarihy: sigez tomda. 5 t.: 1917-1956 ellar. Tez. R. F. Rahmani; fənni meh. D. F. Zahidullina]. Pp. 323-332. Kazan, Tatar.kit.nəshr. (In Tatar)

Soltanbekov, B. (1995). Sеген ach, Sirin! [Reveal Your Secret, Sirin!]. Mədəni жomga. 21 iyul'. (In Tatar)

Sultanbekov, B. (1995). Sirin: prervannyi vzlet [Sirin: An Aborted Takeoff ]. Respublika Tatarstan. 28 oktiabria. (In Tatar)

Tatar adabiiaty tarihy: sigez tomda. Sirin (18961969) (2017) [History of Tatar Literature: In Eight Volumes. Sirin. (1896-1969)]. 5 t.: 1917-1956 ellar. Tez. 
R. F. Rahmani; fənni meh. D. F. Zahidullina]. Pp. 323332. Kazan, Tatar.kit.nəshr. (In Tatar)
Tinchurin, K. (1935). Sovet adabiyaty [Soviet Literature]. No. 11, pp. 72-75. (In Tatar).

\title{
ШАГЫЙРЬ СИРИННЕН ИДЕЯ-ЭСТЕТИК КАРАШЛАРЫ ЭВОЛЮЦИЯСЕ
}

\author{
Әнвәр Мәгъдәнур улы Шәрипов, \\ Яр Чаллы дәүләт педагогия университеты, \\ Россия, 423826, Яр Чаллы шәһәре, Низаметдинов ур., 28 нче йорт, \\ anvar41.41@mail.ru.
}

\begin{abstract}
Мәкаләдә 1920 - 1950 еллар татар әдәбияты үсешенә зур өлеш керткән шагыйрь һәм поэмалар авторы Сириннең (Сирин Хәниф улы Батыршин) идея-эстетик карашлары үсеше социаль һәм мәдәни аспектта тикшерелә. Яңа чыганакларга, әдәби-тәнкыйди материалга һәм архив материалларына нигезләнеп, шагыйрь тормыш юлы һәм әдәби дөньясы яңа фактлар һәм мәгълүматлар белән баетыла. Мәкалә темасының яңалыгы шулар белән билгеләнә. Төрле елларда чыккан газета, журнал битләрендәге мәкаләләр барланып, 1920-1950 еллар әдәби хәрәкәтен тикшергән галимнәрнең монографик хезмәтләрендәге аерым күзәтүләр бөртекләп жыелып, Сирин поэзиясенең өйрәнелү тарихы күзаллана. Шагыйрь поэзиясе шагыйрьнең тормыш фактлары, ул ижат иткән әдәби-тарихи чор үзенчәлекләре, архив материаллары белән үрелеп анализлана. Мәкалә авторы чагыштырма-тарихи, типологик, биографик методларга мөрәжәгать итеп, шагыйрь әсәрләрен, бер яктан, эчке бәйләнешләр, икенче яктан, Гареб һәм Шәрык әдәби-мәдәни диалогында бәяли. Сирин идея-эстетик карашларының эволюциясен тикшерү барышында, шагыйрь ижатының үсеш баскычлары, аларның үсеш тенденцияләре һәм төп сыйфатлары аерып чыгарыла; тема-мотивлар, жанрлар үзгәрешенә һәм тасвирый алымнарга күзәтү ясала.
\end{abstract}

Төп төшенчәләр: татар поэзиясе, идея-эстетик караш, әдәби бәйләнешләр, мотивлар, жанрлар.

Сирин (Сирин Хәниф улы Батыршин, 14.12.1896 - 23.11.1969) - 1920-1960 еллар татар поэзиясе үсешенә, ижади эзләнүләр алып барып, аны яңа формалар белән баетуга, аның мотивларын hәм жанрларын киңәйтүгә үзеннән зур өлеш керткән каләм ияләренең берсе.

Шагыйрь Сирин әдәбият мәйданына 1919 елларда чыга, әмма ижаты 1930 елларда гына бәяләнә башлый. Турыдан-туры шагыйрьгә багышланмасалар да, әдәбият мәсьәләләре тикшерелгән мәкаләләрендә аның ижатына кагылышлы фикерләрне беренче булып Ф. Сәйфи-Казанлы [Ф. Сәйфи-Казанлы, 1930], Г. Нигъмәти [Нигъмәти, Совет әдәбияты, 1930], [Нигъмәти, Яңалиф, 1931] hәм Х. Бәдигъ [Бәдигъ, 1932] әйтеп чыга. Шагыйрьнең 1931 елда латин графикасында “Тамчылар" исемле шигырьләр жыентыгы басылып чыккач, аңа игътибар арта төшә [Сирин, 1931]. Сирин ижатын махсус анализлаган беренче мәкаләне Закир Гали яза [Гали, 1931]. Ул шагыйрьнең 1931 елда чыккан “Тамчылар" китабына кереш сүз буларак та урнаштырыла.
1920 елларның икенче яртысы - 1930 елларда татар әдәбият белемендә хөкем сөргән сыйнфыйлык принцибы, вульгар социологик карашлар Сирин ижатын дөрес бәяләүгә нык кына комачаулый. "Совет әдәбияты” журналының 1933 елгы 12 санында әдипнең "Кышкы чәчәкләр" шигыре басылып чыга [Сирин, Совет әдәбияты, 1933]. Журналның 1934 елгы 1-2 санында ук, шигырьнең эчке рухын аңламыйча, аңа бары сыйнфый күзлектән чыгып бәя биреп, Сиринне тәнкыйтьләгән мәкаләләр дөнья күрә. Мәсәлән, Гомәр Гали шагыйрьне "социалистик жәмгыять чынбарлыгының алдынгы идеяләре белән коралланмауда" гаепли [Гали, 1934, б. 92-93], ә Н. Баян исә “Кышкы чәчәкләр”нең актуаль темага язылмаганлыгын күрсәтә [Баян, 1934, б. 94-95]. Бу урында Сириннең Татиздатның авыл хужалыгы бүлеген житәкләгән Нур Баянның кул астында эшләвен искәртеп китү урынлы булыр.

Мәкаләләр, авторларының вульгар-социологизм белән авыруларын күрсәтү белән беррәттән, Сиринне гаепләүгә дә Үз өлешләрен кертәләр. 1935 елда Татарстан язучыларының 
съездында сөйләгән речендә Татарстан Язучылар берлеге рәисе Кави Нәжми шагыйрьне "әдәбият эшенә турыдан-туры катнашудан читтә торуда", “совет властена каршы, социалистик төзелешкә каршы көрәшүдә”, “контрреволюцион юлга китүдә”, “советка каршы әсәрләр язуда" гаепләп чыга [Нәжми, 1935, б. 72-75]. Доклад буенча фикер алышуларда чыгыш ясаган К. Тинчурин да шул рухта сөйли: "Бу черек кешеләрнең калдыгына каршы көрәшүдә либераллык күрсәтү һич ярамаган эш булыр иде... Яхшылап тәрбияләгәндә дә төзәлмиләр икән, аларны остарак тәрбиячеләр кулына тапшырырга кирәк" [Тинчурин, 1935, б. 72-75]. Мирсәй Әмир бу ялгыш бәяләрне куәтли төшә: “Ул кулак семьясыннан чыгып, солтангалиевчелеккә катнашып йөргән кеше. Ул күптәннән инде безнең идеология белән килешә алмаган бер кеше... Хәзер инде аларга каршы башка чара күреләчәк һәм күрелергә тиеш” [Әмир, 1935, б. 66-68]. Сириннең “Тегүче кыз” шигырен “ачыктан-ачык солтангалиевчелек” дип атый. Әлбәттә, мондый чыгышлар нәтижәсез калмый: Сиринне "совет властена каршы пропаганда алып баруда" гаепләп, 1935 елның 22 августында кулга алалар һәм ул биш елга Себергә сөрелә.

Тарихи дөреслек торгызылып, исеме халыкка кайтарылгач, моңа кадәр исеме махсус оныттырылган Сирин рухи мирасы барлана һәм объектив рәвештә бәяләнә башлый. 1959 елда Зыя Мансур мөхәррирлегендә аның 54 бит күләмендә шигырьләр жыентыгы дөнья күрә [Сирин, 1959]. Сирин ижатын өйрәнүгә яшь язучы Мәгъсүм Латифуллин зур өлеш кертә. Ул Баулы мәктәбендә укытучы булып эшләгәндә, шагыйрь белән танышып, аның белән якыннан аралаша, шагыйрьнең туган авылы Кәрәкәшлегә дә кайтып йөри; нәшер итү нияте белән, әдипнең әсәрләрен туплый. 1959 елда Сириннең “Шигырьләр" китабына рецензия язып бастыра [Латифуллин, 1959, 9 декабрь]. Сирин исән чагында ук М. Латифуллин ике тапкыр шагыйрь әсәрләренең жыентыгын төзеп, Татарстан китап нәшриятына тапшыра. Шагыйрьнең 56 шигырен $\mathrm{Y}^{3}$ эченә алган “Октябрь нурлары” жыентыгы 1961 елда әзерләнә. Аңа да М. Латифуллин "Сирин һәм аның поэзиясе” дигән кереш сүз язган була [Сирин архивы, Латифуллин мәкаләсе]. 34 шигырь урнаштырылган "Сайланма әсәрләр" дигән икенче жыентык 1963 елда төзелгән. Ләкин ни сәбәпледер, ул китапларның берсе дә басылып чыкмаган.
1970 еллардан башлап, Сириннең һəp түгәрәк юбилеена багышланган мәкаләләр дөнья күрә. Шагыйрьнең 80 еллыгына Ә. Шәриповның "Үзенчәлекле шагыйрь" [Шәрипов, 1976, 5 декабрь)], 90 еллыгына “Трибун шагыйрь" [Шәрипов, 1986, 7 декабрь)], Сафа Сабировның “Давыллы еллар жырчысы” [Сабиров, 1986, 13 декабрь] язмалары һәм “Казан утлары” журналының редакцион мәкаләсе [Редакцион мәкалә, Казан утлары, 1987] басыла. Алар Сириннең матбугатта чыккан шигъри әсәрләрен пропагандалау, ижади уңышларын күрсәтү юнәлешендә генә язылганнар. Ә менә аның нахакка гаепләнү һәм кулга алыну тарихын беренче тапкыр ачыклап, жәмәгатьчелеккә житкерүче галим Булат Солтанбеков була. Совет чорында күп кешеләр “халык дошманы” исеме тагылган Сириннең хәтта исемен әйтергә дә курыкканнар. СССР таркалгач, Б. Солтанбеков, НКВД архивындагы “дело”лар белән танышып, "Серең ач, Сирин!..” [Солтанбеков, 1995, 21 июль] hәм "Сирин: прерванный взлет" [Солтанбеков, 1995, 28 октября] мәкаләләрендә тарихның моңа кадәр билгесез кала килгән сәхифәләрен бәян итеп, күпләрнең “күзен ачты”. Р. Мостафинның да Сириннең 100 еллыгы уңае белән язылган “Такташның көндәше" [Мостафин, 1996, 3 май] hәм "Кыш сайрамый сандугач..." [Мостафин, Казан утлары, 1996] мәкаләләре шагыйрь тормышын hәм ижатын өйрәнүгә яңа мәгълүматлар өстәде.

Сириннең 100 еллыгына А. Юнысованың “Кыш сайрамый сандугач” [Юнысова, 1996, 20 декабрь], Ф. Галимуллинның “Каләменнән тамдырып канын...” [Галимуллин, 2015], 110 еллыгына Ә. Шәриповның “Шагыйрь Сириннең тормыш һәм ижат юлы” [Шәрипов, 2006] мәкаләләре басыла, шагыйрьнең туган авылы Кәрәкәшледә Сирин ижатына багышланган фәнни конференция була. Бу чарада Ютазы муниципаль районы башлыгы урынбасары Р.К. Хәкимова, Әлмәт Язучылар оешмасы рәисе Данил Салихов, Әнвәр Шәрипов, Сириннең энесе Мәхәсиннең улы Рифкать Батыршин h.б.лар чыгыш ясый. Сириннең 120 еллык юбилее (2016 ел) уңаеннан Ютазы урта мәктәбендә тантаналы рәвештә татар теле һәм әдәбияты укытучыларының һәм укучыларның республикакүләм фәнни-гамәли конференциясе үткәрелә. Анда Ютазы-Баулы төбәгеннән генә түгел, ә Түбән Кама, Чирмешән, Спас, Яңа Чишмә һәм Башкортостанның Туймазы районы вәкилләре дә катнаша. 9-11 сыйныф укучылары 
өчен ике секциядә 19, татар теле һәм әдәбияты укытучылары секциясендә 11 доклад тыңлана, 5-7 сыйныф укучылары арасында Сирин шигырьләрен яттан сөйләү бәйгесендә 16 укучы чыгыш ясый.

1990-2020 елларда Ә. Шәрипов, Сирин ижатын татар әдәбияты фәне ирешкән казанышлар ноктасыннан шәрехләү, аның күңел жимешләрен укучыларга житкеру hәм пропагандалау максатында, аеруча актив һәм нәтижәле эшли: [Шәрипов, 1997], [Шәрипов, 1998], [Шәрипов, 2011], [Шәрипов, 2007], [Шәрипов, 2014], [Шәрипов, Казан утлары, 2016, №12, б. 128-129], [Шәрипов, Казан утлары, 2016, №1], [Шәрипов, Казан утлары, 2016, №12, б. 130-160] [Шәрипов, Мәдәни жомга, 2016], [Шәрипов, Ислам һәм төрки дөнья..., 2016] h.б.лар.

“Мәйдан” журналының 2015 елгы 12 саны тулысынча Сирин ижатына багышланып, анда Ә. Шәрипов әзерләгән материаллар басыла: Сириннең илле шигыре, дүрт проза әсәре, бер мәкаләсе, Сирин турында Б. Солтанбеков, Р. Мостафин, Ф. Галимуллин, Ә. Шәрипов мәкаләләре, К. Рәхим, С. Сабиров, Л. Бадыйкшан, Я. Игәнәй истәлекләре, басылып чыккан китапларының исемлеге һәм аның тормышын чагылдырган күп санлы фоторәсемнәр китерелә. Журналның бу саны бүгенге көндә Сирин ижаты турында иң тулы мәгълүматларны туплаган басма булып санала.

Сирин ижатын өйрәнү юлында аның замандашларының истәлекләре дә кыйммәтле. Шундыйлардан Миргалим Шакиржанов, Кәрам Әхмәтжанов, Кәшиф Рәхим, Әхмәт Исхак, Шафигъ Камалетдинов, Рафаэль Мостафин, Сафа Сабиров, Локман Бадыйкшан, Ямаш Игәнәй, Урал Уралов, Мәгъсүм Латифуллин, Рифкать Батыршин h.б.ларның язмалары.

Шагыйрь Сирин (аның $\mathrm{Y}^{3}$ исеме Мөхәммәдсәйрин) 1896 елның 14 декабрендә Татарстанның Ютазы районы Кәрәкәшле авылында Гыйльман улы Мөхәммәдхәниф гаиләсендә бишенче бала булып дөньяга килә. Соңрак ул үзенә псевдоним итеп Сирин исемен ала һәм шул исем белән әдәбият тарихына кереп кала.

Сирингә ярлы тормышның ачы михнәтен күп күрергә туры килә. Аны кайгы артыннан кайгы, фажига артыннан фажига көтеп тора. 1910 елларда ачлы-туклы яшәу аркасында, Сириннең бер абыйсы hәм бер энесе вафат була. 1916 елда йортлары яна; аны көч-хәл белән сипләп, яшәрлек хәлгә китерәләр.
Гражданнар сугышы вакытында, акларның снаряды төшеп, сыерлары һәм атлары үлә. 1921 елдагы ачлык вакытында әнисе Хөсникамал ачлыктан (көзән жыеруыннан) вафат була. Бу фажига турында Сирин, өзгәләнеп, болай дип яза: “Алабуталар чабып, никадәр тырышсам да, әнине үлемнән коткарып булмады. Ачлык белән чирләп, кадерле анам үлде минем!..Миңа дөньяның кызыгы калмады. Инде нишләргә?.. Үзем дә үпкә шеше һәм тиф белән чирләдем, кыш буе чирләгәннән соң, бераз аякка баскач, “Бәлки, Казанда үлми калырмын” дип Казанга киттем. Анда да ачлык, икмәкнең килосы бер миллион сум икән. Мине Кабан күле буендагы зур йортка урнаштырдылар" [Сирин, 2016, б. 160]. Ә әтисен гражданнар сугышы вакытында аклар, “коммунистлар ягында булганы өчен” мәчет баганасына бәйләп кыйныйлар; ул, шул кыйнаудан мантый алмыйча, бераздан вафат була. Боларның барысы да булачак шагыйрьнең йөрәге аша уза. Язмышының шундый рәхимсез, кырыс сынаулары Сиринне бөтен гомере буена озата бара.

1910-1915 елларда күрше авылы Бәйрәкә мәдрәсәсендә укыган чакта ук, ул, гаделсезлекне күреп, бай һәм мулла малайларыннан көлгән шигырь-такмаклар чыгара башлый һәм аларны мәдрәсәдә яки тулай торакта оештырыла торган яшерен кичәләрдә укый: Бүген бай малае Әхми / Акча бирде муллага. / Мулла “Кирәкми!", дисә дә, / Нишләптер куль ала. / Әхми дә шатланды эчтән: / "Укымыссам да мактар!... / Шулай акча бирә-бирд, / Үзенүзе ул camap [Сирин архивы, Латифуллин мәкаләсе]. Мондый чыгышлары өчен бай малайлары аны кыерсыталар, күрә алмый башлыйлар. Әмма яшүсмер үжәтлек белән андый такмаклар әйтүдән туктамый. Шулай итеп, шәкерт вакытында ук Сириндә жәмгыятьтәге гаделсезлекләргә карата нәфрәт тойгысы барлыкка килә; еллар узу белән, ул тагын да зурая, арта төшеп, 1930 еллар ижатында иң югары ноктасына житә.

Сирин, беренче тапкыр шагыйрь буларак, халык алдында 1914 елның 16 февралендә чыгыш ясый: ул көнне Кәрәкәшледә күренекле журналист һәм жәмәгать эшлеклесе ФәридәиФатыйманы соңгы юлга озату мәрасиме уздырыла. Бу чарага тирә-күрше авыллардан да күп халык жыела. Менә шунда Сирин үзенең “Фәридәи-Фатыйма ханым рухына" дигән беренче шигырен укый. "Син үлсәң дә, әмма ләфзан, / Син мәгънәи үлмәдең. / Керде ж⿻асәден кабергә, / Әмма үзең кермәдең̧” [Сирин архивы, 
Латифуллин мәкаләсе], дигән юллар халык күңеленә бик хуш килә; авыл халкы соңыннан да, Фәридәи-Фатыйма хакында сөйләшкәндә, Сириннең шушы шигырен дә искә төшерә торган булалар. Мәрсия шул ук елда "Сөембикә" журналында басылып чыга. 1915 елда ул жир сөрү, иген игү эшләрен күмәкләшеп эшләргә чакырган “Сарутлык жир” әсәрен яза. Болар әле яшь шагыйрьнең каләм сынау чоры тәжрибәләре була.

Сирин 1914-1917 елларда башта туган авылында, 1916 елда Әсәйдә, 1917 елда Азнакай мәктәбендә укытучы булып эшли. Төрле жәмәгать эшләрендә, әдәби кичәләр оештыруда актив катнаша. Октябрь революциясен ул әнә шулай укытучы булып каршы ала. Бөгелмәдәге өч еллык укытучылар әзерләү семинариясендә укыган елларында, ул комсомолга керә. Бөгелмә өязендә беренче комсомол ячейкасының (РКСМ) татар-башкорт секциясе оештырылгач, Сирин ул секциянең секретаре итеп сайлана. Кәрәкәшле, Бәйрәкә, Татар Кандызы һәм башка авылларда комсомол ячейкалары төзүдә башлап йөри. Гражданнар сугышында кулына корал тотып катнашуы да мәгълүм. Бөгелмәдә укыган чакта, “Сәнәкчеләр" фетнәсе белән бәйле сугыш вакыйгалары Сиринне дә Үз эченә бөтереп алып кереп китә. М. Латифуллин мәкаләсендә Сириннең, 1920 елның март аенда Бөгелмә районы Кодаш авылында сәнәкчеләр белән бәрелешкәндә, чак кына һәлак булмый калуы турында языла [Сирин архивы, Латифуллин мәкаләсе].

Сириннең чын мәгънәсендә ижат итә башлавы 1919 елларга, гражданнар сугышы чорына туры килә. Тормышының Бөгелмә чорында яшьлек ялкыны белән ижат ителгән көчле инкыйлаби рухлы шигырьләре аша әдәбиятка килеп керә. Әдәби әсәрләрен ул Бөгелмәдәге “Якты юл”, Самарадагы “Яңа көч”, Казандагы “Эшче”, Томскидагы “Кызыл шәрекъ" газеталарында бер-бер артлы бастыра. Шул рәвешле, “Сириннең ижат юлын ике чорга бүлеп карарга мөмкин: 1920-30 еллар һәм 194060 еллар" [Шәрипов, 2017, б. 325]. Шуларның беренче чоры аеруча актив, ашкынулыдавыллы hәм күпкырлы булып, әдәби жәмәгатьчелектә зур резонанс тудыра.

Сириннең 1920 еллар ижатында төп урынны Гражданнар сугышы темасы алып тора. Бу темага ул “Кызылармеец хаты” (1919), “Сәлам сезгә, кызыл бөркетләр!” (1920), “Кызыл гаскәргә” (1922), “Атлы шлемнар" (1927), “Кызылармеец атлар” (1928) шигырь- ләрен багышлый. Алар барысы да оптимистик пафос, революцион романтика, киләчәк тормышка тирән ышаныч белән сугарылган. "Гомумән, егерменче еллардагы коммунистик идеяле шигъриятне оптимистик рухлы дип атарга мөмкин. Чөнки шагыйрьләрнең күпчелеге, h.Такташ кебек үк, бу яңа хәлләрнең бер көн килеп күпчелеккә бәхет, иминлек тәэмин итәчәгенә ышана иде. X. Сириннең “Безнең йөрәкләр" шигырендә бу өмет аеруча ачык гәүдәләнә” [Галимуллин, 1998, б. 118], дип яза Ф. Галимуллин.

1925 елларда шагыйрьнең “Сикерт атың! (Кавалерия маршы)” (1925) әсәре бигрәк тә популяр була. Шагыйрь шигырьнең эчке ритмына зур әһәмият бирә: аллитерация алымына мөрәжәгать итеп, ат тоякларының тавышларын хәтерләтә торган сүзләр генә куллана, шигырьнең музыкальлек ягына басым ясый: Әй, командир! / Бир команда! / Сөйгән amblм, / Чaпmap атымм! / Tbin-mbin басып, / Am уйнатып, / Атлат атың!! / Атлат атың! [Сирин, 1931, б. 6].

Шагыйрь Кызыл гвардиягә дан жырлап, аның уңышларына сөенә:

Атлы шлемнар,

Сезгә бүләк жырым,

Тавышларын үзегез

аңлагыз!

Урам халкы,

Сез дә сак булыгыз,

Бир команда:

Жинү якын!

Жиңү якын!

Тып-тып басып,

Ат уйнатып,

Атлар килә, тапталмагыз! Сикерт атың! [Сирин,

Әй, командир!

1931, б. 7]

1921 елда ачлык башлангач, Бөгелмә семинариясендәге укулар туктатыла. “Ачлар тавышы” дигән әсәрендә (1921) Сирин ачлыкның үзәк өзгеч картинасын сурәтли: Ярльь илгә ярлылар баш; алтын, көмеш ж⿻ирдә таш, / Төрле чүп-чар, алабута безнең илдә булды аш. / Юк әле, түзми күңел, жсан тартыша, сызыла йөрәк, / Бер телем икмәк сорап тетри багырь, өзелә үзәк [Сирин, 1968, б. 169]. Әлеге социаль мотив белән керешеп киткән иген игү темасына “Яз - игенчегә" (1922), “Сарутлык жир” (икенче вариант, 1924) әсәрләре ижат ителә. Беренче шигырендә ул авыл кешесен тизрәк кырга чыгарга өнди: “Ашык тиздән - үлем биргән бу ачлык китсен бездән”. "Сарутлык жир”ендә шагыйрь жир эшкәртүне фәнни нигезгә куеп, марксизм өйрәтүләрен дә файдалану кирәклеген әйтә.

Ижатының башлангыч чорында ук Сирин Тукай шигъри мәктәбенә мөрәжәгать итеп, бөек 
шагыйрьдән ижади осталыкка өйрәнә. Аңардан үрнәк алып, Шәрекънең классик газәл, касыйдә, мәснәви жанрларында ижат итә башлый. Шагыйрьнең 1920-30 еллардагы шигырьләре белән Тукай әсәрләре арасында типологик параллельләр үткәрергә мөмкин. Тукайның “Эштән чыгарылган татар кызына” (1909) белән Сириннең “Авыл кызына” (1920) әсәрләрен тематик һәм образлар уртаклыгы бәйли: ике әсәрдә дә яшь татар кызының елау мотивы гәүдәләнеп, аларның күңел халәте “мәюсь”, “залим", “күңел” кебек образлар, эпитетлар ярдәмендә сурәтләнә. Әмма Тукайда “залим” булып татар бае саналса, Сирин “залим” символы аша иске тормышны күз алдында тота. Тукайда татар кызының чарасызлыгы сурәтләнә, ә Сирин исә гражданнар сугышына киткән егетен сагынып, күз яшьләрен түгүче кызны: “Күn тә үтмәс, менә кайтып житәр / Жан сөеклен көләч йөз белән, / Мена, киләчәгең нинди матур / Рахәтләнеп гомер итәрсең”, - дип юата [Кызыл Шәрекъ, 1920, 6 август].

Тукайның “Даһигә” (1913) әсәре белән Сириннең “Диңгезгә” (1920) шигырьләре мәснәви формасында язылудан тыш, охшаш рифмалар, мотивларга ия. Тукай үз әсәрендә милли-азатлык хәрәкәте турында уйлана hәм газиз халкын колониаль изүдән коткару, аны ижтимагый-мәдәни яңарышка алып чыгу юлларын эзләгән Даһи образын ижат итә. Ә “Диңгезгә” шигырендә Сириннең үзенең диңгез дулкыннарына да буйсынмас, көчле, ашкын, бунтарь образы калкып чыга. Диңгезгә эндәшеп, шагыйрь болай ди:

$\begin{array}{ll}\text { Ниндәй дулкыннарга } & \text { Ул шулай күзгә күренә, } \\ \text { атсаң да, барыбер } & \text { ут түгел, юк, нур бит ул! } \\ \text { батмамын! } & \text { Пакь вә саф, ап-ак } \\ \text { һәм үлеп, суың төбендә } & \text { күңелле бер фәрештә, } \\ \text { дә череп ятмамын! } & \text { нур бит ул! } \\ \text { Миндә көч, гайрәт вә } & \text { Тарта яшь, дәртле } \\ \text { дәрт бар, күкрәгемдә ут } & \text { күңелне үз янына алга ул, } \\ \text { яна, } & \text { Киң колачлап мин йөзәм } \\ \text { Мин күрәмен алда - анда } & \text { шунда, минемчөн Алла } \\ \text { ялтыраган ут әнә! } & \text { ул! [Сирин, 1920, № 40]. }\end{array}$

Сирин, Тукайның “Булмаса” газәленә (1908) ияреп, үзенең "Булмаса" шигырен (1920) яза. Икесе дә 15-15 үлчәмендә ижат ителсәләр дә, шагыйрьнең остазы газәл жанрын, ә Сирин касыйдә белән мәснәви формаларын сайлаган. Тукай шагыйрь күңелен дәртләндереп торучы гүзәл зат, гүзәллек шаһы - былбылга мәдхия жырласа, Сирин исә, мәхәббәткә сәяси эчтәлек салып, шигырьдә коммунист исемен йөрткән кешенең ярлы халык мәнфәгатен кайгырту, аңа хезмәт итү идеясен үткәрә: “Булмаса күңелдә халькка мәхәббәт хисләре / Булма коммунист, якын килмә бүтән уйлар белән” [Якты юл, 1920, № 41].

Билгеле булганча, Г. Тукай үлеменең түгәрәк даталары ижат әһелләрен һәрвакыт активлаштырып тора. Бу хәрәкәттән Сирин дә читтә калмый һәм ул шагыйрьнең үлеменә ун ел тулу уңае белән “Безнең яшьләр (Тукайның “Яшьләр"енә ияреп, жавап урынында)" дигән шигырен ижат итә. Икесе дә касыйдә жанрында язылган, әмма монда да Тукай белән Сирин шигырьләренең идея юнәлеше төрле: әгәр остаз шигыре, 1905 елгы революциядән соңгы кара реакция елларында язылып, төшенкелек, киләчәккә өметсезлек мотивлары белән сугарылган булса, Сирин шигыре инде, киресенчә, революцион романтика, авторның яңа тормышка ныклы ышанычы белән өретелгән. Реакция елларындагы төшенкелекне, өметсезлекне Тукай болай сурәтли: Бара милләт зәгыйфь, абныр-абынмас, / Сүнә ящьләрдә ут кабныр-кабынмас./ Кичә якты вә милли бер күңелдән / Бүген тычкан утылдай нур табылмас. [Тукай, 2011, б. 135]. Сириннең “Безнең яшьләр"ендә бөтенләй икенче пафос: шагыйрь, яңа жәмгыять төзү идеаллары белән рухланып, оптимистик рухта яза: Йөрәккә уm кабынган, мәнуге сүнмәс, / Яна күкрәктә дәртләр, һич суынмас. / Көч алдык, калтырау юк юльбблзда, / Диябез яшьләр: “Бу күкрәк мәнуге тунммас!” [Сирин, 1923, 15 апрель]. Әдәби әсәр Тукай фикерләренә капма-каршы булган идея белән тәмамлана: Kbıзыл байрак mотыл без юлга чыктылк, / Барырбыз сонггача, һичкем абынмас! [Сирин, 1923, 15 апрель].

1923 елда Сирин Казанда Татар рабфагында белем алган елларда ижади яшьләр белән таныша: Муса Жәлил белән бер төркемдә укый. 1923-1925 елларда Сириннең ижтимагый-сәяси hәм әдәби-эстетик карашлары эволюция кичерә. Шул чор идеологиясе шаукымына бирелеп, шагыйрь Ислам диненә, дини өйрәтмәләргә каршы чыгыш ясый. Дин әһелләрен тәнкыйтьләү мотивы аның "Еласыннар... Мин еламыйм" (1923), “Бер шәехнең идеалистик логикасы” (1925), “Тынычлык кошлары” (1926), “Шөһрәт” (1929) әсәрләрендә тасвирлана. “Тынычлык кошлары"ндагы түбәндәге өзек, халык арасына таралып, ул елларда хәтта көйләп-жырланып та йөртелгән: Алласы да калмасын, / Mулласы да 
чалмасын /алып ташласын! / Безнең кебек тир түгеп, / Безнең кебек бил бөгеп, / эшлап ашасын! [Сирин, 1926, 24 май].

Тиздән Сирин ижади кыйбласын рус әдәбиятына юнәлтә һәм шигырьләрен, Маяковскийдан үрнәк алып, зур аудиторияләрдә кычкырып укуны күздә тотып ижат итә башлый, шуның белән татар әдәбиятында сөйләм шигырен үстерүгә үзеннән зур өлеш кертә. Ленинга багышланган "Утлы хәбәр" шигырендә (1924) ул, хезмәт ияләре юлбашчысы үлеменә бөтен халыкның кайгыруын, әтиәнисенең дә елавын сурәтләү белән бергә, "Кулак, муллалар бу үлемгә шатланмасыннар. Ленин яши, Ленин - безнең йөрәкләрдә!” дип белдерә. Шушы ук фикер аның Ленин үлеменең 4 еллыгына багышланган “Ленинга һәйкәл" (1928) шигырендә дә үткәрелә.

1925 елда рабфакны тәмамлаган Сирин бер ел Бөгелмәдә “Сабанчы” газетасында эшләп алгач, 1927 елның көзендә Казанга яңадан әйләнеп кайтып, Көнчыгыш дәүләт педагогия институтына укырга керә. Монда ул h. Такташ, Г. Кутуй, Х. Туфан, Ә. Исхак һ.б.лар белән таныша, бөтен тырышлыгы белән белем алуга, ижат эшенә бирелә [Шәрипов, 2017, б. 324]. Студент елларын (1926-1930) Сириннең тормышта да, поэзиядә дә Үз-үзен эзләве, “эзләнү чоры” дип атарга мөмкин.

Сирин 1924 елда Г. Кутуй һәм Г. Толымбай житәкчелегендә төзелгән “Сулф” (“Сул фронт”) исемле язучылар күмәгенә керә. Шагыйрь тормышындагы бу факт Әхмәт Исхак истәлегендә теркәлеп калган [Исхак, 1987]. Билгеле булганча, бу елларда Сирин аралашып яшәгән h. Такташ, X. Туфан, Г. Кутуй, К. Нәжмиләр, поэзиядә үз урыннарын табарга омтылып, төрле экспериментлар үткәрәләр. Сирин дә 1927-1928 елларда әсәрләренең формасына зур игътибар бирә. "Көнлиләр" (1927), “Безнең кайгылар” (1928) шигырьләрендә катлаулы образлар белән мавыгып, әсәрнең эчтәлеген икенче планда калдыра. Әмма Сириннең мондый мавыгулары озакка бармый, бер-ике елдан ул үзенең бу экспериментларыннан арына.

Шагыйрьнең студент елларында көтелмәгән бер хәл була: аны совет властена каршы булуда гаепләп, 1927 елда кулга алалар. Ялгыз камерага ябылып, бер ай утыргач кына иреккә чыгаралар. Бу вакыйгадан соң Сирин күңеленә курку кереп оялап, аны һәр минут "Мине тагын кайчан чакырырлар икән? Исән калырмынмы икән?” дигән сорау борчып тора башлый. Шуңа да карамастан, Сирин шул шартларда да ихлас күңелдән партия яклы булып кала. Ул милли рамкаларда гына калырга теләмичә, рус һәм бөтендөнья поэзиясе идея-эстетик казанышларын өйрәнә. Шуның нәтижәсе буларак, ижатының тематикасы киңәя, шагыйрьнең үзүзенә ышанычы арта. Маяковскийга ияреп язылган “Идәнгә төкермәгез!” (1928), “Кытай жыры (Кытай шагыйре Ши-Кингтан)” (1928), "Гейне фикере" (1929) кебек әсәрләре аның үз өстендә житди эшләгәнлеген күрсәтәләр.

Сирин эзләнә, поэзиядә Ү3 стилен, Ү3 шигъри формасын булдырырга, эчтәлек белән форманың берлегенә ирешергә тырыша. Маяковскийдан үрнәк алып, шигырьнең трибунлык сыйфатына басым ясап ижат итәргә омтыла. Әсәрнең сәнгатьлелегенә ирешүдә ул бер алымны - hәр сүзне аерып алып, аның тирән мәгънәсен ачып салып, аларны бер-бер артлы юлдан-юлга тезеп бару алымын куллана. Бу исә автордан шигырьнең эчке ритмын нечкә тоемлауны, ачык яңгырашлы рифмалар сайлап алып язуны таләп итә. Беренче шигырьләреннән үк Сирин шушы юнәлештә тәжрибәләр ясый: “Энәләр” (1922), “Тегүче кыз” (1925) әсәрләре шундыйлардан. Шагыйрь ижатындагы бү күренешкә әдәбият галиме Г. Нигъмәти дә игътибар иткән. Матур әдәбиятта тел элементларының роле турында ул болай дип яза: “..., игътибарга икътисад ясауга авазлар ярдәме белән сурәт бирә торган сүзләр куллану аноматопея (аноматопея. - Г.Н.) дә хезмәт итә. Мәсәлән, төшү, бәрелүне гади сүзләр белән аңлатып язу бар; шулай ук аларны төшү, сугу тәэсирен биргән авазлар кулланып язу бар. Соңгы алым аноматопея дип атала. Татар шигырендә бу алымнарны шагыйрь Сирин күп кенә кулланып яза" [Нигъмәти, б. 108]. Монографик хезмәт авторы да мисалга Сириннең “Тегүче кыз” шигырен китерә.

1927 елда Сирин шушы алым белән иң күренекле “Язгы тамчылар" шигырен яза. Бу әсәрдә ул, бер яктан, охшаш яңгырашлы сүзләрне сайлап, тамчылар тавышын чагылдырырга омтылса, икенче яктан, әсәрнең эчтәлегенә дә тирән мәгънә сала:

$\begin{array}{ll}\text { Там, } & \text { Язгы тамган } \\ \text { Там, } & \text { Тамчыларның } \\ \text { Тамчы, там, } & \text { Музыкасын тыңладым. } \\ \text { Тамуыңны яратам. } & \text { Шуңар } \\ \text { Тамчы-тамчы } & \text { Тамчыланып } \\ \text { Жырларыңны } & \text { Тамды } \\ \text { Ак кәгазьгә таратам. } & \text { Күңелемдәге уйларым. } \\ & \text { [Сирин, 1959, б. 11]. }\end{array}$


Шагыйрь язгы тамчыларның поэтик матурлыгын гына жырлап калмый, чор таләбеннән якын килеп, бу күренешне жәмгыять тормышы белән дә бәйли, шуның белән әсәрнең ижтимагый ролен дә көчәйтүгә ирешә: Taм, / Там, / Тамчы, там / Бергә тамыйк ичмасам! / Мин дә тамчыланып тамыйм, / Көрәшләрдә аксын кан! [Сирин, 1959, б. 12]. Бу әсәр басылып чыгу белән (1927), бик тиз халык арасына таралган, халык аңа көй дә язган. Шул көй безнең көннәргә кадәр килеп житеп, бүген дә балалар бакчаларындагы музыка дәресләрендә жырлана.

Шушы алым белән Сирин 1929 елда үзенең программ әсәрләренең берсен - "Минем трагедиям" (икенче исеме "Йөрәк каны белән”) фәлсәфи шигырен ижат итә. Сирин шагыйрь шәхесенең һәм ижатының, поэзиянең совет жәмгыятендәге урыны, вазифасы, роле турында уйлана. Яктылыкка омтылу идеалы белдерелеп, киләчәккә оптимизм белән сугарылган бу әсәрендә ул үзенең поэтик ижатын болай сурәтли:

$\begin{array}{ll}\text { Бу - минем } & \text { Яшисе килә, } \\ \text { уйларым, } & \text { күп яшисе. } \\ \text { Бу - ритм. } & \text { Көләсе килә, } \\ \text { Бу - минем } & \text { күп көләсе. } \\ \text { йөрәгем тибүе. } & \text { Киләсе көннәрнең } \\ \text { Бу - минем } & \text { көлгәнен } \\ \text { канымның } & \text { күрәсе килә. } \\ \text { тәнемнән } & \text { Их, } \\ \text { жыр булып } & \text { Күрәсе! } \\ \text { кәгазьгә } & \text { Күрәсе! } \\ \text { күчүе... } & \text { Күрәсе!!! [Сирин, 1959, } \\ & \text { б. 6-7]. }\end{array}$

Шулай итеп, 1930 елларда татар поэзиясендә башка беркемнекенә дә охшамаган “Сирин стиле" барлыкка килә. Бу Такташ стиле дә, Хәсән Туфан стиле дә түгел. "Сирин стиле”, бер яктан, хыялның көчле булуы, тирән эмоция, лиризм һәм революцион романтика белән сугарылган булса, икенче яктан, яңгыравыклы ритмы, халыкның йөгерек, гади, матур сөйләм телен файдалануы белән үзенчәлекле була. Шагыйрь музыкаль яңгырашлы сүзләр белән төрле халәт-хәрәкәтләрне күз алдына китереп бастыра. Шигырьдә музыкальлек өстенлек ала, аңарда төрле тавышлар яңгыраган төсле, тәэсирле итеп бирелә, шул ук вакытта автор шигырьнең эчтәлегенә дә тирән мәгънә сала белә: hәр әсәренең киң ижтимагый яңгырашы турында кайгырта. Поэтик идея белән публицистиканы органик бергә кушып алып барырга омтыла.

Сирин Такташ белән якын дус булган, алар үзара ярыша-ярыша ижат иткәннәр. Казанның зур залларындагы әдәби кичәләрдә икесе дә яңгыратып шигырьләр укып, яшьләрнең иң яраткан шагыйрьләренә әверелгәннәр. Ямаш Игәнәй бу фактны шагыйрьнең 100 еллыгына багышланган мәкаләсендә Сириннең үз сүзләре белән раслый: “Сәхнәнең бер ягыннан Такташ, икенче ягыннан мин килеп чыга идем. Укып жибәрәбез шигырьне, зал ни эшләргә белми, сихерләнә, илаһи шаукымга тоташ уралып, тылсымлы-серле халәтнең иң югары ноктасында бөтерелә", - дип сөйләгән иде ул бер очрашу вакытында" [Игәнәй, 1996, б. 96].

Такташ белән дуслык аларның ижатларында да чагыла: замандашлар шигъриятендә байтак кына охшашлык-аваздашлык бар. Алар бер үк темага яки бер үк мотивка икесе ике төрле әсәрләр язган. Юкка гына Р. Мостафин Сиринне "Такташның көндәше" дип атамый бит [Мәдәни жомга, 1996, 3 май]. Мисал өчен: Октябрьнең ун еллыгына Такташ үзенең "Үпкәлим" шигырен, ә Сирин "Урам уртасында" әсәрен багышлый; 1927 елда Такташ кызыл кавалеристларга багышлап “Атлы сугышчыга”, ә Сирин “Атлы шлемнар” шигырен яза. Мондый аваздашлык хәтта Такташ үлеменнән соң да дәвам итә. Кызларның кыска күлмәк киеп йөрүләренә шагыйрь “Жырым сиңа булсын” (1927), ә Сирин “Бала итәкле озын күлмәкләр” (1933) шигырен, кар явудан этәрелеп китеп беренчесе “Ак чәчәкләр" (1929), ә икенчесе “Кышкы чәчәкләр" (1933), халыкара күләмдә тыныч тормыш турында Такташ “Лорд Чемберленга СССР крестьяны һади Такташтан жавап нотасы" шигырен (1927), ә Сирин "Халыкара сугышка каршы Конгресс"та Сириннең сөйләгән беренче рече" поэмасын (1933) ижат иткәннәр.

1929 елда Педагогия институтын тәмамлагач, Сирин Казанның М. Вахитов исемендәге мәктәбендә татар теле һәм әдәбиятын укыта. 1930 елда аны Татиздатның авыл хужалыгы бүлегенә редактор итеп эшкә чакыралар. Анда ул 1935 елның августына, ягъни кулга алынганга кадәр эшли.

Сириннең 1930-1935 еллар ижатында заманның иң актуаль мәсьәләләре күтәрелә. Аның бик популяр, зур күләмле "Булмый! Булмый!” (1930) шигыре шул елларның көнүзәк мәсьәләсе - авыл хужалыгын 
коллективлаштыру темасына багышланган. Әсәр нигезенә салынган "Машиналы күмәк тормыш төзеп жибәр!” фикерен автор укучы күңеленә антитеза алымы ярдәмендә житкерә: бер якта - хосусый милекчелеккә нигезләнгән иске тормыш; икенче якта - ижтимагый милеккә нигезләнгән яңа жәмгыять, яңа тормыш. Күмәк тормышның өстен һәм файдалы булуын шагыйрь авыл кешесенә гади сүзләр белән аңлатып бирә. “Ашлыгыңны жилгәрәмсең, жилгәр, жилгәр” сүзләрен рефрен итеп куллана һәм, кабатланган саен, алар әсәрнең ижтимагый мәгънәсен тирәнәйтә баралар. Бу әсәр ул елларда бик популяр булып, аны һәр кичәдә сәхнәдән сөйләгәннәр. Мәсәлән, бу шигырь күренекле артист Мохтар Мутин репертуарында да үзәктә торган.

Партиянең XVI съезды карарларын, “Ленин кадаган маяклар”дан читкә тайпылмыйча, халык арасына күбрәк тарату идеясен гәүдәләндергән “Күп тарат!” шигыре 1930 елда ижат ителә. Татарстан республикасы төзелүгә 10 ел тулуга багышланган “Татарстан” (1930) шигырендә өлкәнең уңышларын күреп, күңелен шатлык хисе биләгән лирик герой сурәтләнә. Студентлар тормышын Сирин "Микроскоплы күзләр”, “Койрыклы студент”, яшьлек-мәхәббәт темасын "Каш астыннан”, "Үзбәк кызы “Дәрдем бар”га”, “Башлыгыңның зәңгәр, ак кикриген...” кебек шигырьләрендә тасвирлый. Балалар өчен "Көз" (1929), “Кыш" (1929), "Яз" (1929), “Жәй” (1929), “Кеше” (1930), “Бә-ә-ә дә мә-ə-ə” (1931), “Корыч атлар” (1931), “Тимер юл” (1931), “Трамвайлар ник туктаган?” (1932), “Жиләк бакчасы” (1933) исемле кечкенә генә рәсемле китаплар, ә 1931 елда “Тамчылар" исемле күләмле генә шигырьләр жыентыгын чыгара [Шәрипов, 2017, б. 329].

1931 елда Такташның вакытсыз үлеменә нисбәтле язылган "Зәңгәр күзле егет юк инде" шигырендә Сириннең бу вакыйгага фажигале мөнәсәбәте, бик авыр кичерешләре сурәтләнә: Яфракларга уен бәйләп йөргән / Көчле шагыйрь / бүген күмелде. / Тамбов урманы күк / Шаулап ускән / Бөек талант хәзер юк инде [Мәйдан, 2015, № 12, б. 30]. Новатор шагыйрь вафат булса да, лирик герой аның ижатының үлемсезлегенә, ерак киләчәккә барачагына ихлас күнелдән ышана: Ни сөйлисез, / Шагыйрь Үләмени? / Ул бит тели бергә яшарга. / Илебезнең көчле бер талантын / Ник килдегез / Монда күмәргә? [Мәйдан, 2015, № 12, б. 31].

Шулай да 1930 елларда социалистик үзгәртеп коруларга чын күңелдән ышанган
Сирин күңлендә яңа жәмгыятькә шөбһәле, икеләнүле караш бөреләнә башлый: жәмгыятьтәге гаделсезлекләргә борчыла, аларның сәбәбен ачарга омтыла. Ихлас күңелдән совет жәмгыятенең патриоты булып та, үзен урынсыз гаепләүләрнең, эзәрлекләнүләренең сәбәбен аңларга тели. Әкренләп моның серенә дә төшенә: тышкы яктан кызыл лозунглар белән төреп алынган совет системасының эчендә мәкерлелек, алдашу, кыерсыту, байлык бүлешү ятканлыгын һәм үзенең шул система эчендә яшәргә мәжбүр булуын аңлап ала. Шагыйрьнең хөрлек, ирек сөюче бунтарь жаны мондый икейөзлелеккә, мәкерлелеккә каршы нәфрәт белән тула: аның шәкерт чорында ук бөреләнгән нәфрәте, гаделсезлеккә каршы көрәше югары дәрәжәгә житә. Ижатында борылыш башлана: ул жәмгыятьтәге гаделсезлекләрне, икейөзлелекне ачы сатира утына тота. Эзоп теленә мөрәжәгать итеп, тискәре күренешләрне мәсәл жанры аша камчылый: "Кәжә белән сарык" (1931), “Сатучы һәм сатып алучы” (1932), “Карга белән саескан” (1934), “Ишәк белән куян” (1935) һ.б. Ә менә "Бала һәм хөкүмәтләр" (1932), “Тормыш ярына басып" (1933), “Күңелле күңелсез” (1933), “Кем белә, кем белми” (1935) шигырьләрендә дәүләтләрнең коралланулары, ижтимагый тәртипләрнең кешенең иреген кысуы тәнкыйтьләнә. НКВД изоляторында булып чыкканнан соң, Сирин “Син кайда булдың?" диючеләргә" (әсәрнең икенче исеме "Мин кайда булдым? - Мин шунда булдым!") дигән шигырь язган (“29 / VII -33” дигән дата куелган). Ул анда үзенең ялгыз камерадагы тормышын зур кыюлык белән реаль детальләрдә ачык төсләр белән сурәтли: “Мин булдым шунда, кайдадыр шунда / Сандугачлар оя ясамый. / Мин булдым шунда, кайдадыр шунда / Чьппьвллар да килеп сайрамьй... / Булды көннарем, бетте өннарем / Бер сүз сөйлашерга ж⿻өдәдем. / Иректә йөргән, матур көн күрган / Чебеннарнең көнен көнладем" [Сирин, 2015, № 12, б. 46].

Киләчәкнең өметсезлеге, тотрыксызлык, hәр көнне, hәр сәгатьтә үзеңне алып китүләрен көтеп яшәү, шагыйрь күңелендә эзсез калмый: Сирин ижатында хәтта үлем темасы гәүдәләнүгә китерә. Күңеленең фажигале кичерешләрен, хисләр бәрелешен "Хис" шигырендә (1933 елның 29 сентябре) болай тасвирлый:

Минем йөрәк, Анда хисләр,

Муенгамы баулар салып, Үз-үземне тотып 
Көчле хисләр өзелеп

тартыша.

Нишлим?

Кайсы жиңәр?

Йөрәк барыр

Кемгә, кайсына? асыйммы?

Әллә шунда -

Кабан буйларына барып,

Сасы күлгә күмим

башымны? [Сирин, Хис,

1933]

Авторга якын торган лирик герой әжәлгә мөрәжәгать итеп, аны үзенә чакыра: Әй, әжсәл! / “Матур” ажслл! / Килче әле минем каршыга! / Килче, багърем, / Сөй син мине, / Булчы минем карчыгам! [Сирин, Хис, 1933].

Күнеле белән Сирин бу тормыштан китәргә әзерләнеп, тормыш белән хушлашу чигенә барып житә. “Хушыгыз!” шигырендә (аның бер варианты "Кыш сайрамый сандугач" дип атала, 1934 ел, 23 ноябрь) ул болай ди: “Хушыгыз, әй дусларым, / Дус-ишләрем, хуш, мин китәм. / Мәнуге дә кайтмам инде, / Күрешмәбез инде бүтән. / Ут төртәм таудай теләкләргә, / Жан сөйгән эиләремә. / Чик куям антым белән мин / Дөрләп торган хисләремә". Шигырь болай тәмамлана: Хушыгыл, таллар, юкәләр, / Хушыгыз, әй, алмагач! / Кичерегез магыйрь Сиринне, - / Кыи сайрамый сандугач [Сирин, 1934, 23 ноябрь].

Сирин шигъри дөньясы яңа алымнарга байый барып, ул ижатында хат яки телеграмма формасына мөрәжәгать итә. Ижат иреге мотивы үзәккә алынган "Лермонтовтан хат" (1933) әсәрен ул Лермонтов исеменнән яза һәм вафат булган шагыйрь авызыннан мондый сүзләр әйттерә: Чьнбарлькны дөньяда сөйләргә / Мөмкинме әле?.. Бер хат сальгыз!.. [Сирин архивы, 1933]. Хат яки телеграмма тексты итеп язу алымын “Тукаевтан Сирингә телеграм", “Тумаган балалардан хат”, “Бөтен дөньяга телеграм” дигән шигырьләрендә куллана.

Тормышта шундый янау-куркытулар булуга да карамастан, Сириндә әле оптимистик рух та саклана. “Шәфкать туташы” (1930), “Пушкиннан бер өзек” (1934), “Карлы” (1934) шигырьләрендә ул “киләчәктә бу заманнар узар” дигән өмет белдерә. “Карлы” әсәрендә ул: “Иx-ма! Әле дә үзебез чьлдам, / Йөрәк күнгән кайгыхәсрәткә. / Юкса безнең башны әллә кайчан / Шаитырырлар иде хәсрәтләр" [Сирин архивы, 1934], - дип яза. Юаныч эзләп, ул Гареб-Рус һәм Шәрекъ поэзияләренә мөрәжәгать итә, алардан рухи халәтенә аваздаш мотивларны эзли. "Гажәпләнү (Әбел Галә әл-Мәгарридән)" (1933), “Алтын металл (Шекспирдан)” (1933), Есениннан этәрелеп китеп “Зәңгәр кичтә”, "Алсу кофта, зәңгәр күзләр" (1934) әсәрләре языла. “Алтын металл (Шекспирдан)”, “Каторжаннар" (1933) шигырьләрендә жәмгыятьтәге күп нәрсәнең акчага корылуы тәнкыйтьләнә. Француз шагыйре, сатира остасы Пьер Беранжега (1780-1857) таянып, әхлак темасына “Син бит Гөлсем түгелсең” (1933), “Аучылар” (1934) шигырьләрен яза. Аларда сурәтләнгән вакыйгаларның тышкы күренеше, кинаяле, яшерен мәгънәгә ия булып, шагыйрь яшәгән чорның тотрыклы сыйфатына әверелгән мәкерлелеккә ишарә ясый.

Сирин, лирик жанрлар белән генә чикләнеп калмыйча, лиро-эпик поэмалар да ижат итә. "Кеше" (1930), “Халыкара сугышка каршы Конгресс"та Сириннең сөйләгән беренче рече" (1933), “Ана" (1934) әсәрләре шушы калыпта язылганнар. Балаларга адресланган "Кеше” поэмасында, халык мәсәленә таянып, Кешенең явыз бүредән көчлерәк булуы сурәтләнә. "Халыкара сугышка каршы Конгресста Сириннең сөйләгән беренче рече" публицистик поэмасының башлам өлешендә дәүләтләр арасындагы тынычлык һәм коралсызлану хакындагы фикерләр бәян ителә. Аннан соң дәүләт һәм шәхес проблемасы алга чыгарыла. Рефрен итеп: Даүләт өчен кешеләр яишме? / Кеше өчен малла даүлатлар?/ Кеше өчен даүләтләр яшәсә, / Нигә болай безнен бу эиләр? [Сирин, 2019, б. 91], - юллары алынып, дәүләтләрнең сәясәте гади кешеләрнең шәхес иреген кысуга юнәлдерелгән булуы тәнкыйтьләнә. Поэма ахырында Сирин ясалмалылык, икейөзлелек кебек күренешләргә каршы чыгып, табигый хис белән яшәүчеләрне яклый.

“Ана” поэмасы - шагыйрьне репрессияләүгә сәбәпче булган әсәрләрнең берсе. Бу әсәрдә “Социализм жинә барган саен, жәмгыятьтә сыйнфый көрәш тә кискенләшә бара" дигән Сталин күрсәтмәсенең кан-кардәшлек, туганлык мөнәсәбәтләрен дә кискенләштереп жибәреп, зур бәхетсезлек-фажигаләр китереп чыгаруы тасвирлана. Вакыйга ананың улы исеменнән сөйләнә. Сәяси карашлар, үтә сыйнфый принцип хәтта ана белән баланы да ике капма-каршы якка аера. Унөч бала тәрбияләп үстергән ананы, ике-өч сыер асрауда гаепләп, өеннән куып чыгаралар; ул шәһәр урамында хәер сорашырга калган. Шәһәр урамында ана улына мөрәжәгать итеп, аңардан мәрхәмәтлек сорый. Әмма революция идеяләренә нык бирелгән улы рәхимсезлек күрсәтә: үз әнисен сыйнфый дошман санап, аңа ярдәм итүдән баш тарта һәм әнисенә болай дип жавап бирә: 
Бер кулак пичәте

басылгач,

Үз анам дип сине

якласам,

Нәрсә булыр сыйнфый

көрәштән,

“Кода-кодагыйлык”

ясасам...

Ананың сүзләрендә шул чордагы курку атмосферасы ачык чагыла. Шулай өзгәләнеп торганда, аның кулындагы күкрәк баласы жан бирә. Күренә ки, поэма 1930 елларда махсус күпертелгән сыйнфый көрәшнең никадәр рәхимсез, кешелексез булганлыгын укучыга ачып сала. Татар поэзиясе тарихында әлеге теманы бу кадәр фажигалелек белән өретелгән тирәнлектә күрсәткән башка әсәр табуы авыр.

Нахак бәлаләр, ярлыклар тагылган Сирингә Язучылар берлегендә дә мөнәсәбәт начарлана. P. Мостафин: "Идеологик тотнаксызлыкта" гаепләп, Сиринне Язучылар берлегенә алмыйлар, “формализм”да һәм башка “изм”нарда гаеплиләр”, - дип яза. - Ә сәләтсез шагыйрьләрне, “идеология" ягына карап, бастыралар, бүләклиләр, югары күтәрәләр” [Мостафин, 1996, б. 163]. Поэзиядә үз дәрәжәсен белгән, ачы телле Сирин мондый кимсетүгә ачы сатира белән жавап бирә. Казанда оешкан язучылар төркемен ул “Ат кәмите” дип атый. Язучылар берлеге әгъзаларын тәнкыйтьләп, "Күтәрик бокалларны!” (1934) шигырендә кешеләрнең авыр тормыштан, гажизлектән эчүгә тартылуларын тасвирлый.

“Паганини" шигыре дә (1935) фаш итү рухы белән сугарылган: Паганини бездә юк ул, / Булса да, аңар дөнья тар. / Паганини булмаса бит, - / Поганыйлар бездә бар, [Мәйдан, 2015, № 12, б. 81.]. Моңа кадәр гел генә кызыл төсләрдә сурәтләнеп киленгән совет жәмгыятен “бөек” телнең “поганый” сүзе белән бәяләү, аның кимчелекләреннән ачы көлү хакимияттә утыручыларга ошамый. һәм бу шигырь дә Сиринне гаепләүгә китергән әсәрләрнең берсе була. Шагыйрьнең хәтта Сталинның үзенә дә сарказмга корылган эпиграмма язуы мәгълүм. Тексты сакланмаса да, Булат Солтанбеков мәкаләсендә аның эчтәлеге китерелә: “Сандугачым, hәр жырыңда, син Сталинны мактап жырла. Шул чакта сине күреп алырлар, сиңа "СССРның атказанган сандугачы" исеме бирерләр” дигән сүзләр булган.

Сиринне 1935 елның 22 августында кулга алалар һәм 1936 елның февралендә аны, ирегеннән мәхрүм итеп, биш елга Сиблагка сөрәләр.

Бакчаларда басып йөргән Акчарлагым, жәй эзем калды,

Әнкәй, сиңа бик күп сөйләр сүзем калды. Сау бул, әнкәй, тәнем китте, жаным калды, Жаннан артык күргән ярым, каным калды.

канатың, кил яныма, Сәлам хатлар языйм апак канатыңа.

Сандугачым, син тыныч бул, сайра, иркәм, Мин ирекнең кадрен беләм, сиңа тимәм [Мәйдан, 2015, № 12, б. 45].

- дип сурәтли шагыйрь үзенең туган иленнән аерылуын. Шушы рухтагы авыр, драматик хис-тойгылар, күңел кичерешләре әдипнең "Өстәлемдә бер стакан чәй калды, эчелмәде”, “Яшьлегем яшькә буялып”, “Мунча ташы” кебек әсәрләрендә дә тасвирлана.

Сөргендәге кеше чыдамаслык тормыш шартлары тоткыннарны тәмам йончытып, хәлсезләндереп бетерә. Тәүлегенә 250 грамм икмәк бирәләр, планыңны үти алмасаң, анысыннан да мәхрүм итәләр. Ул анда тимер юл салу эшендә эшли. Көн тудымы, яшәү өчен рәхимсез көрәш бара. Кичерә алмаслык авырлыкларга түзә алмыйча, күпләр үлеп кала. Хәятка мәхәббәте, ихтыяр көче зур булган Сирин кимсетелүләргә, ачлыкка бирешми, исән кала. Сөргендәге тормышын истәлекләрендә ул болай искә ала: “Бик күп еллар узды. Тәндә ит, кан калмады. Әгәр кулны пәке белән киссәң, кызыл кан чыкмый, саргылт су гына чыга; тәнеңдә кечкенә бер жәрәхәт ясалса, аны төзәтергә материал юктан, берничә еллар буе төзәлми” [Казан утлары, 2016, № 12, б. 153].

Ниһаять, биш еллык срогы тулгач, Сирин иреккә чыгып, 1940 елның көзендә туган иленә кайта. Ул бик бетеренгән, хәлсезләнгән, киемнәре тәмам тузып-теткәләнеп беткән була. Бөгелмәдәге энесе Шамилдә өс-башын алыштыргач кына, Кәрәкәшлегә кайтып керә. Бераз хәл алгач, 1941 елда Үз теләге белән Ватан сугышына китә. Мәскәу яны сугышларында катнаша. 1942 елның көзендә, контузия алып, авылга кайта, кышны туган төбәгендә үткәрә. Сәламәтләнә төшкәч, колхоз эшенә чыга: атлар карый, кырдан салам ташый, басуда кар тота. Шул вакытта ул "Кар тотканда" (1942) дигән әсәрен яза. Монда ул тыныч тормышка, табигать кочагында эшләп йөрүгә дан жырлый.

1943 елның язында Сирин яңадан фронтка китә. Шул ук елның ахырында, авыр яраланып, Ташкент госпиталенә жибәрелә. Анда бераз 
сәламәтләнгәч, Кәрәкәшлегә кайта, тагын бар көчен биреп, тырышып колхозда эшли башлый. Сугыштагы батырлыклары өчен "1941-1945 еллардагы Бөек Ватан сугышында Германияне жиңгән өчен”, тылдагы хезмәте өчен “Бөек Ватан сугышы елларындагы фидакарь хезмәт өчен” һәм "Бөек Ватан сугышында Жиңүнең 20 еллыгы” медальләре белән бүләкләнә.

1946 елдан Сирин Баулы районы үзәге Акбуа поселогына күчә. Беръеллык умартачылар курсында укып кайткач, Кәрәкәшле, Ташкичү авылларында умартачы булып эшли.

Сөргеннән кайткач та, Сириннең әдәби эшчәнлеге тукталмый, әмма бераз сүлпәнләнә, элеккеге ярып сала торган кискенлеге йомшара төшә. Шагыйрь 1930 еллардагы “Сирин стиле"нә инде әйләнеп кайтмый, традицион кимәлдә ижат итә. Бу елларда аның туксаннан артык шигыре, бер поэмасы, берничә әкияте языла. Берничә елдан шагыйрьнең сәламәтлеге начарлана: сөргендәге салкын тиюләр, сугыштагы яралар, контузияләр өстенә аңарда туберкулез авыруы башлана. Шулай да әле ул каләмен ташламый. 1962 елда авыруы көчәеп киткәч, Акбуа туберкулез диспансерына кереп дәваланырга мәжбүр була.

Биш еллык сөрген газаплары, сугыштагы тән яралары Сириннең рухын сындыра алмый. 1940-1969 елларда да ул совет жәмгыятендәге гаделсезлекләрне, “кызыллык”ны тәнкыйтьләүне дәвам итә. Көлүне көчәйтү өчен, "социалистик сыбызгы” (“Карт большевик, милиционер һәм кызыл сыбызгы”, 1952), “социалистик агач” (“Матур хатын”, 1956) аллегорияләрен куллана. Сталин үлеменә багышлаган “Шатлыклы үлем" (1953) мәсәлен яза. “Аю белән көзге һәм мин” (1944), "Бал белән балан” (1945), “Кәжә белән сарык” (1958), "Ике үрдәк” (1960), “Дөреслек һәм кәжә” (1961), “Кыскартуга эләккәннәр" (1961), “Күгәрчен, карчыга һәм кеше" (1964) мәсәлләрендә кешеләрдәге ялагайлык, мин-минлек, наданлык, куркаклык, милли чикләнгәнлек тәнкыйтьләнә. "Кыскартуга эләккәннәр" мәсәлендә, мәсәлән, күчерелмә мәгънәдәге ат, куян һәм эт үзара сөйләшәләр: өчесе дә кыскартылуга эләгеп, эштән чыгарылганнар. Бер-берсеннән "Сине ни өчен кыскарттылар?” дип сорашалар. Ат әйтә: "Минем гаебем - күз салмыйча бүтәнгә, урлашуларда катышмый, үз эшемне үтәүдә. Бергә урлашып йөрмәгәч, дошман күрде хуж⿻алар", - ди. Куян әйтә: "Хужсалар минем куркак булуымны белгәннәр, "Монь кыскартсак та, каршы килә алмас”, дигәннәр”,
- ди. Ә этнең жавабы шундый була: “Мuн, $\partial u$, ярый алмадым хужсалар кәефенд. Гомер буе байда эиләп, белмим, ничек торганмын / Бер көн койрык болгар жсирдә, ялгым өреп куйганмын” [Мәйдан, 2015, № 12, б. 83]. Күренә ки, hәр өчесенең жавабы совет жәмгыятендәге тәртипләргә ачы сатира булып яңгырап, алар әле бу елларда да шагыйрьнең рухи ныклыгына дәлил булып торалар.

1941-1969 елларда Сирин шигьриятендә яңа темалар барлыкка килә: сугыш темасы (“Ванюша белән Катюша” (1943), “Хурлыклы исем - колонизатор" (1960), “Безнең бурыч” (1961)); хорафатлар, имеш-мимешләрне тәнкыйтьләү (“Дөнья бетми мәңге дә!” (1961)), Юрий Гагаринның космоска очуы белән горурлану (“Күкләр капкасы ачык”та (1961)); диктаторлыкны кире кагу ( “Канцлер Аденауэр hәм шагыйрь-доктор"); матурлык эченә яшеренгән усаллыкны, кешелексезлекне тәнкыйтьләү (“Матур хатын” (1956) поэмасы) һ.б.лар.

1958-1959 елларда Сирин зур ижат осталыгы сорый торган татар балалар әдәбиятын үстерүгә үзеннән зур өлеш кертә. Алар төрле темага язылып, яшь буында матур әхлак сыйфатлары, матурлыкка мәхәббәт тәрбияләүгә хезмәт итәләр: мәктәп, белем алу, тәрбия темасы (“Кире малай” (1942), “Ана белән бала” (1948), “Нәни оратор” (1951), “Биек баскыч, көмеш ачкыч"(1958), “Белем тавы” (1960) h.б.лар); яшьлек-мәхәббәт темасы (“Тәмле уйлар, дәртле хисләр белән” (1943), “Егет белән кыз” (1956), һ.б.лар). Авыл тормышы, авыл халкының яшәеше, горефгадәтләре, төрле күренешләре 1940 елда язылган “Яз көннәре. Яңгырлы көн”, “Алладан сыер сорау яки элекке күршелек”, "Ике ат"; "Күчә торган инеш" (1945), "Югалган сабан" (1951) шигырьләрендә чагылыш таба. Үзе гомеренең бер баскычында ямь һәм яшәү гаме тапкан умартачылык hөнәре поэтик югарылыкка күтәрелеп, "Умырзая һәм бал корты”, “Зур кунак”, “Кортлар шәһәре”, “Бал бабай” әсәрләрендә тасвирлана. Халык жырларына ияреп, Сирин нечкә юмор белән сугарылган "Кызлар жырлыйлар", "Яңа жырлар”, “Әй, алым син, гөлем син!” кебек шигырьләр ижат итә. 1960 елларда чәчмә белән язылган “Бер мужик, өч поп”, “Мактаулы бүрек" әкиятләрендә кешеләрдәге ялагайлык, икейөзлелек сыйфатлары тәнкыйтьләнә.

Сөргеннән кайткач, Сирин фикердәш, жан тынычлыгы эзләп булса кирәк, Хәсән Туфан 
белән элеккеге дуслык жепләрен янартып жибәрә. Алар бер-берсе белән хат алышалар, кунакка да йөрешәләр. Шул очрашуларның берсендә Хәсән ага Сирингә үзенең 1958 елда чыккан “Жырлар. Шигырьләр” китабын яшел кара белән тирән мәгънәгә ия булган сүзләр язып бүләк иткән: “Сирин! Дөньяда икенче кат яшәгән кабатланмас матур көннәребез истәлеге булсын бу сиңа. Ихтирам белән Х. Туфан. 27. XI. 61." Сириннең бер хатында (1961 елның 6 ноябре) шундый юллар бар: “Туфан!.. Исән-сау кайтып життеңме? Сине озаткач, безгә шактый күңелсез булды. Аерылу хисләрен кичердек...”. Димәк, Х. Туфан 1961 елның көзендә Баулыда, Сириндә кунакта булган (бу вакытта Сирин Баулының “СМУ - 4" бистәсендә, 5нче баракның бер бүлмәсендә яшәгән).

Алда әйтелгәнчә, Сирин гомеренең соңгы елларын туберкулез авыруы белән көрәшеп үткәрә. Иң соңгы әсәрләреннән булган “Бер кисәк” дигән шигырендә (1964) шагыйрь әле киләчәк планнары турында бәян итә: Теләкләрем чиксез минем, хисапсыз; / Йөрәк тибүләрем санль, хисапльл. / Исәп-хисап эиләрем күп ничаклы, / Тәндә жсқаным кунак, белмим, ничакль?? [Сирин архивы, машинкада басылган текст].

Шагыйрь Сирин озак һәм каты авырудан соң 1969 елның 23 ноябрендә Баулыда вафат була һәм шәһәрнең татар зиратына жирләнә. Әдипнең тууына 90 еллыкны билгеләп үткән көннәрдә аның каберенә Баулы районы хакимияте тарафыннан Сириннең барельефы төшерелгән истәлекле зур таш куела. Баулыда, Ютазы районы үзәге Ырыссуында һәм Кәрәкәшле авылында Сирин Батыршин исемендәге урамнар бар. Бөтен гомерен һәм талантын жәмгыятьтә гаделлек урнаштыру өчен көрәшкә багышлаган шагыйрь турындагы истәлек безнең көннәрдә әнә шулай саклана. 1917 елгы Октябрь борылышыннан соң илдә башланган ижтимагый, икътисадый, әдәбимәдәни үзгәрешләрне, хәвефле вакыйгаларны лирик геройның драматик һәм фажигале кичерешләре аша гәүдәләндергән Сирин шигърияте катлаулы һәм каршылыклы совет чынбарлыгының тарихи елъязмасы булып тора.

\section{Әдәбият}

Әмир М. Совет әдәбияты. 1935. № 12. Б. 66-68.

Бәдигъ Х. Яңалиф. 1932. № 9-10.

Баян Н. Казан утлары. 1934. №1-2.

Габдулла Тукай. Әсәрләр. Академик басма. Алты томда. 2 том. Казан: Татар. кит. нәшр., 2011. 384 б.
Гали 3. Сирин шигырьләре // Яңалиф. 1931. № 4. Б. 51-54.

Гали Г. Яңа баскычка // Казан утлары. 1934. №1-2

Галимжсан Нигъмәти: тормылшы, язмышы фәнни-методик эшчәнлеге / Т.Ш. Гыйлажев редакциясендә. Казан: “Бриг” нәшрияты, 2018. 252 б.

Галимуллин Г. Каләменнән тамдырып канын... // Мәйдан. 2015. № 12.

Галимуллин Ф.Г. Эстетика һәм социологизм: 2030 нчы еллар татар әдәбиятында эстетика кануннарының һәм социологизм таләпләренең үзара мөнәсәбәте. Казан: Мәгариф, 1998. 223 б.

Игәнәй Я. Эз сызып атылган йолдыз // Аргамак. 1996. № 12. Б. 96.

Исхак Ә. Бәләкәй генә бер истәлек // Чаян. 1987. № 3. Б. 6.

Латифуллин М. Шигырьләр // Совет Татарстаны. 1959. 9 декабрь.

Латифуллин М. Сирин һәм аның поэзиясе (Машинкада 22 бит. Сирин архивында саклана).

Мостафин P. Такташның көндәше // Мәдәни жомга. 1996. 3 май.

Мостафин P. "Кыш сайрамый сандугач" // Казан утлары. 1996. № 12. Б. $161-164$.

Нәжсми К. Совет әдәбияты. 1935. № 11. Б. 72-75.

Нигъмәти Г. Совет әдәбияты. 1930. № 4.

Нигъмәти Г. Утыз беренче елга кергәндә (Әдәбият һәм яңа көчләр) // Яңалиф. 1931. № 1. Б. 34-38.

Редакцион мәкалд. // Казан утлары. 1987. № 2.

Сабиров C. Давыллы еллар жырчысы // Хезмәткә дан. 1986. 13 декабрь.

Сәйфи-Казанль Ф. Яңалиф. 1930. № 1. 40).

Сирин. Диңгезгә // Якты юл. 1920. 25 ноябрь. (№

Сирин. Хәзерге яшьләр // Татарстан. 1923. 15 апрель. май.

Сирин. Тынычлык кошлары // Сабанчы. 1926. 24

Сирин. Тамчылар [Кереш сүз авт. 3. Гали]. Казан: Татиздат, 1931. 60 б.

Сирин. Кышкы чәчәкләр // Совет әдәбияты. 1933. №12.

Сирин. Хис, 1933 ел. НКВД архивыннан М. Латифуллин алган шигырь (Сирин архивында саклана).

Сирин. Лермонтовтан хат, 1933 ел. // НКВД архивыннан М. Латифуллин алган шигырь (Сирин архивында саклана).

Сирин. Карлы. 1934 ел // Сирин архивы, машинкада басылган текст.

Сирин. Хушыгыз! 23.11.1934 // Сирин архивы, машинкада басылган.

Сирин. Шигырьләр / мөх. 3. Мансур. Казан: Татар. кит. нәшр., 1959. 54 б.

Сирин. Ачлар тавышы // Ялкынлы еллар поэзиясе [Төз. С. Мортазин]. Казан: Татар. кит. нәшр., 1968. 169б. 
Сирин. Шигырьләр, проза әсәрләре. Шагыйрь турында мәкаләләр, истәлекләр // Мәйдан. 2015. № 12. 3-97 б.

Сирин. Тормыш хатирәләре // Казан утлары, 2016. № 12. Б. 130-160.

Сирин. "Халыкара сугышка каршы Конгресс"та Сириннең сөйләгән беренче рече // Безнең мирас. 2019. № 11. Б. 90-92.

Сирин. "Ана" поэмасы // Безнең мирас. 2020. № 8. Б. 68-69.

Солтанбеков Б. Серең ач, Сирин! // Мәдәни жомга. 1995. 21 июль.

Султанбеков Б. Сирин: прерванный взлет // Республика Татарстан. 1995. 28 октября.

Тинчурин K. // Совет әдәбияты. 1935. № 11. Б. $72-75$.

Шәрипов Ә. Үзенчәлекле шагыйрь // Социалистик Татарстан. 1976. 5 декабрь.

Шәрипов Ә. Трибун шагыйрь // Социалистик Татарстан. 1986. 7 декабрь.

Шәрипов Ә. Шагыйрь Сирин: тормышы һәм ижаты // Фән һәм мәктәп. 1997. № 2, 3.

Шәрипов Ә. Сирин фажигасе // Татарстан. 1998. № 2. Б. 78-92.

Шәрипов Ә. Шагыйрь Сириннең тормыш һәм ижат юлы // Г. Тукайның тууына 120 ел тулуга багышланган фәнни-гамәли конференция материаллары. Яр Чаллы, 2006, Б. 81-89.

Шәрипов Ә. Каләмнән тамдырып канымны // Тарихи-мәдәни мирас. 2011. № 1, 2.
Шәрипов Ә. Сирин шигырьләре // Мәйдан. 2007. № 3. Б. 99-108 б.

Шәрипов Ә. Йөрәк каны белән язылган // Безнең мирас. 2014. № 7. Б. 54-61 б.

Шәрипов Ә. Шигърияттә Сирин стиле // Казан утлары. 2016. №1. Б. 138-145.

Шәрипов Ә. Сирин Батыршинның тууына 120ел // Казан утлары. 2016. №12. Б. 128-129.

Шәрипов Ә. Тормыш хатирәләре // Казан утлары. 2016. №12. Б. 130-160.

Шәрипов Ә. Сириннең Тукайга шигъри жавабы // Мәйдан. 2016. № 4. Б. 57-62.

Шәрипов Ә. Шагыйрь Сириннең “Ана” поэмасы // Ислам һәм төрки дөнья: Мәгариф, тел. әдәбият, тарих һәм дин проблемалары: VIII Халыкара Тюркология конференциясе материаллары жыентыгы (Россия, Татарстан республикасы, Алабуга, 2016 ел, 22 апрель) / жав. мөх. А.3. Нигамаев. Казан: Казан университеты нәшрияты, 2016. Б. 157-159.

Шәрипов Ә. Газаплы еллар аша // Мәдәни жомга. 2016. № 48-49.

Шәрипов Ә.М. Сирин (1896-1969) // Татар әдәбияты тарихы: сигез томда. 5 т.: 1917-1956 еллар / [төз. Р.Ф. Рахмани; фәнни мөх. Д.Ф. Заһидуллина]. Казан: Татар.кит.нәшр., 2017. Б.323-332.

Юнысова A. "Кыш сайрамый сандугач” // Ватаным Татарстан. 1996. 20 декабрь.

Ялкынлы еллар поэзиясе [төз. С. Мортазин]. Казан: Татар. кит. нәшр., 1968. 169 б.

\title{
ЭВОЛЮЦИЯ ИДЕЙНО-ЭСТЕТИЧЕСКИХ ВЗГЛЯДОВ ПОЭТА СИРИНА
}

\author{
Анвар Магданурович Шарипов, \\ Набережночелнинский государственный педагогический университет, \\ Россия, 423826, Н.Челны, ул. Низаметдинова, д. 28, \\ anvar41.41@mail.ru.
}

В статье идейно-эстетические взгляды поэта Сирина (наст. имя - Сирин Ханифович Батыршин), внесшего огромный вклад в историю татарской литературы 1920-50-х гг., рассмотрены в динамике и в социокультурном контексте. Дополнительные сведения, почерпнутые из архивных литературно-критических статей и источников, расширяют наши представления о жизненном и творческом пути создателя стихотворений и поэм - в этом и состоит новизна нашего исследования. В статье систематизирован материал о степени изученности творчества Сирина в монографиях и обзорных статьях литературоведов о литературной жизни 1920-50 гг. Творчество поэта и своеобразие литературной обстановки, которая его окружала, изучаются на основе архивных материалов в единстве друг с другом. С помощью сравнительно-сопоставительного, типологического, биографического методов анализа выявлены внутренние взаимосвязи, существующие между стихотворениями поэта, а также особенности его диалога с культурой и литературой Востока и Запада. В ходе анализа эволюции идейно-эстетических взглядов Сирина определены этапы развития его творчества, ключевые тенденции и особенности, характер изменений, происходящих в тематике, жанрах, мотивах, особенности поэтики.

Ключевые слова: татарская поэзия, идейно-эстетические взгляды, литературные взаимосвязи, мотив, жанр. 